NBSIR 81-2372

\title{
Development of An Energy Test Method for A Dedicated Water-Heating Heat Pump
}

U.S. DEPARTMENT OF COMMERCE

National Bureau of Standards

National Engineering Laboratory

Center for Building Technology

Building Equipment Division

Washington, DC 20234

November 1981

Issued January 1982

Prepared for

U.S. Department of Energy

Washington, DC 20545

and

lak Ridge National Laboratory

lak Ridge, Tennessee $\mathbf{3 7 8 3 0}$ 


\section{Printed in the United States of America. Available from National Technical Information Service U.S. Department of Commerce 5285 Port Royal Road, Springfield, Virginia 22161 NTIS price codes-Printed Copy: A04 Microfiche A01}

This report was prepared as an account of work sponsored by an agency of the United States Government. Neither the United States Government nor any agency thereof, nor any of their employees, makes any warranty, express or implied, or assumes any legal liability or responsibility for the accuracy, completeness, or usefulness of any information, apparatus, product, or process disclosed, or represents that its use would not inf ringe privately owned rights. Reference herein to any specific commercial product, process, or service by trade name, trademark, manufacturer, or otherwise, does not necessarily constitute or imply its endorsement, recommendation, or favoring by the United States Government or any agency thereof. The views and opinions of authors expressed herein do not necessarily state or reflect those of the United States Government or any agency thereof. 


\title{
DEVELOPMENT OF AN ENERGY TEST \\ METHOD FOR A DEDICATED \\ WATER-HEATING HEAT PUMP
}

\author{
C. Andrew Wan \\ Robert L. Palla, Jr. \\ James E. Harris
}

U.S. DEPARTMENT OF COMMERCE

National Bureau of Standards

National Engineering Laboratory

Center for Building Technology

Building Equipment Division

Washington, DC 20234

November 1981

Issued January 1982

Prepared for

U.S. Department of Energy

Washington, DC 20545

and

Oak Ridge National Laboratory

Oak Ridge, Tennessee 37830

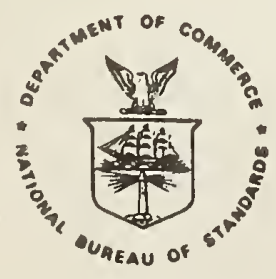

U.S. DEPARTMENT OF COMMERCE, Malcolm Baidrige, Secretary NATIONAL BUREAU OF STANDARDS, Ernest Ambler, Director 


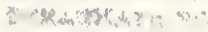

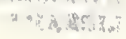

$\therefore-\frac{\pi}{4}$ 


\section{FOREWORD}

This report is submitted to the U.S. Department of Energy/Oak Ridge National Laboratory by the Building Equipment Division, National Bureau of Standards, under the Interagency Agreement No. EW-78-I-05-5750, Task C. The purpose of this report is to present a test method for the water heating heat pump coupled with a 50-gallon electric water heater and an appropriate formula for calculating the energy consumption of the system based on test measurements. The work was focused on a unit having a water flow control device. Subsequent to the initiation of this work, other manufacturers developed units which do not have a water flow control device. An approach is suggested to normalize this feature but verification of its reasonableness has not been done.

In general, the International System of Units (SI) is used as the primary system with the customary equivalent in parentheses. In other cases, only the customary units are provided where customary usage is well established or where consistency with the units of the published test procedure in the Federal Register is provided. Table 6 for conversions of units is provided on page 43 .

Many of the usual rating features depend on the size and materials of the water heater. Because this study involved only one water heater and hook-up to the water heating heat pump, the general applicability of the results is limited.

Thus, although the report provides insight for preparation of an acceptable test procedure, it should be used only as a starting point. 

$\begin{array}{lr}\text { I. INTRODUCTION } & 1\end{array}$

II. DEFINITIONS 2

1. Water-Heating Heat Pump 2

2. Temperature-Sensitive Water Flow Control Valve 2

3. First Pass

4. Latter Passes

III. TEST METHOD - PROPOSED MODIFICATIONS 2

1. Installation 2

2. Test Room 3

3. Thermocouple Installation - Interior 3

4. Thermocouple Installation - Test Room 3

5. Test Room Ambient Temperature 4

6. Test Room Relative Humidity 4

7. Setting the Tank Thermostat 4

8. Water Supply

9. Setting the Flow Control Valve (FCV)

10. Recovery Efficiency

11 Standby Loss

12. Recovery Efficiency of Latter Passes 6

13. Power Input Determination 6

IV. RATIONALE AND COMMENTS FOR TEST METHODS AND PROCEDURES USED 6

1. Installation 6

2. Test Room 7

3. Thermocouple Installation - Interior 7

4. Thermocouple Installation - Test Room 7

5. Test Room Ambient Temperature 7

6. Test Room Relative Humidity 8

7. Setting the Tank Thermostat 8

8. Water Supply 8

9. Setting the Flow Control Valve 8

10. Recovery Efficiency

11. Standby Loss 9

12. Recovery Efficiency of Latter Passes 10

13. Power Input Determination 10

V. LABORATORY TEST PROGRAM $r$

1. Introduction 10

2. System Description 10

3. Test Facilities and Instrumentation 12

4. Tests and Results 13

5. Performance Indices $\quad 18$

$\begin{array}{lr}\text { VI. CONCLUSIONS } & 19\end{array}$

REFERENCES 
Table 1 Results of recovery efficiency tests

Table 2 Results of standby loss tests (based on $E_{r}=2.40$ )

21

Table 3 Water draw schedule

Table 4 Daily energy consumptions calculated based on measured recovery efficiency and standby loss and assigned temperature rises and water consumption

Table 5 Comparison of calculated and measured daily energy consumption 
Figure 1 Water heater heat pump setup

Figure 2 Schematic of water supply system for draw tests

Fiugre 3 Schematic representation of data acquisition/reduction system

Figure 4 Temperature inside the water storage tank during recovery tests

Figure 5 Average water temperature, ambient air temperature, and heat pump power during recovery test

Figure 6 Heat pump inlet and outlet water temperature during recovery test

Figure 7 Recovery test efficiency and power input vs. ambient temperature, $\mathrm{T}_{i}-12.8^{\circ} \mathrm{C}, \mathrm{T}_{\mathrm{f}}=62.8^{\circ} \mathrm{C}$. FCV setting $=46.1^{\circ} \mathrm{C}$

Figure 8 Temperature inside the water storage tank during standby test

Figure 9 Average water temperature, ambient air temperature, and heat pump power during standby test

Figure 10 Standby loss versus ambient air temperature

Figure 11 Temperature inside water storage tank during a draw test

Figure 12 Average water temperature and ambient air temperature during draw test

Figure 13 Temperature inside the water storage tank during recovery test with the FCV removed

Figure 14 Temperature inside the water storage during recovery test with $\mathrm{FCV}$ setting $=48.3^{\circ} \mathrm{C}$

Figure 15 Heat pump inlet and outlet water temperature during recovery test with FCV setting $=48.3^{\circ} \mathrm{C}$

Figure 16 Recovery efficiency at different FCV settings with a $24^{\circ} \mathrm{C}$ ambient temperature

Figure 17 Average water storage tank temperature and ambient temperature during cooldown test

Figure 19 Coefficient of performance versus heat pump inlet temperature, with a $27^{\circ} \mathrm{C}$ ambient temperature 
Modifications of the Department of Energy test procedure for water heaters "Uniform Test Method for Measuring the Energy Consumption of Water Heaters" were made to include a dedicated water heating heat pump, system equipped with a 50-gallon electric water heater tank. Also presented are laboratory tests and results which provided the basis for the test methods used. Tests included determination of recovery efficiency, standby loss, and water heater jacket loss -- all under static or no-draw conditions -- and a dynamic test in which water is withdrawn according to a "typical-use" schedule. Energy requirements predicted by the proposed (static) procedure were in good agreement with measured energy consumption for the dynamic test in limited testing.

Key words: energy conservation; energy consumption; flow control valve; heat pump; stratification; test method; water heater 


\section{INTRODUCTION}

Conventional water heaters (WH) for which accepted test methods exist use oil, gas, or electricity as the energy source. With the effort to conserve energy in recent years, novel appliances that require less energy usage to satisfy hot water needs have been developed. One of these appliances is an integral type heat pump water heater (HPWH), for which a test method was recently developed [1]* by the National Bureau of Standards (NBS) for the Department of Energy (DOE)/Oak Ridge National Laboratory (ORNL). This report now concerns the separated type appliance; namely, a dedicated water heating heat pump (WHHP) connected to an electric water heater (EWH) tank.

The WHHP is a separate heat pump (HP) system intended for retrofit to an existing electric, oil, or gas-fueled water heater and as a substitute for the electric heating elements or burner. The WHHP refrigerant loop consists of an evaporator, a compressor, a condenser, a refrigerant expansion device, a dryer, and the connecting tubes. A fan blowing ambient air over the evaporator enhances heat transfer between the evaporator and the ambient air. A pump circulates water from the storage tank through the condenser.

The WHHP is connected to the WH tank with pipes or hoses. The drain of the WH is connected to the inlet of condenser via the circulation pump. The hot water outlet of the WH is connected to the outlet of the condenser via a temperature-regulated flow control valve (FCV). Therefore, the pump, condenser, connecting pipes or hoses, and WH form the closed water loop. When operating, the WHHP transfers heat through the condenser to the water which is circulated through the WH. The FCV regulates the flow rate of water passing through the condenser to maintain an approximately constant exit water temperature. For the WHHP used in this investigation, the FCV throttles the flow rate to a minimum of $0.2 \mathrm{gpm} * *$ for a minimum water temperature to the WH of $115^{\circ} \mathrm{F} * *$. The FCV opens, increasing to a maximum flow rate of $1.5 \mathrm{gpm} * *$ for water to the condenser greater than $115^{\circ} \mathrm{F}$.

The HPWH described in Reference 1 and the WHHP-EWH system investigated here differ in several important ways. The HPWH previously investigated consisted of a heat pump (HP) and a water heater combined within one assembly. The condenser coil of the HP was physically located in the water storage tank and transferred heat from ambient air via the HP refrigerant directly to the surrounding tank water during HP operation. The WHHP-EWH system has an external condenser in a circulating water loop for transferring heat from the refrigerant to water. Also, the WHHP may be fitted to any water storage system while the HPWH is an integral system with the condenser and storage tank supplied as a unit. The different design and operation necessitates using a different test method for a WHHP-EWH. The development of this test method was the objective of the present study.

*Numbers in brackets indicate references.

**These values apply only for the particular WHHP model tested. 
The results of the study are presented in the next four sections. In Section II, a list of new definitions is given. Proposed test method modifications are given in section III, and the rationale for these modifications are given in Section IV. The results of an experimental study of the WHHP connected to a 50-gallon EWH are given in Section $V$. The experimental study was conducted in order to develop the modifications to the WH test methods to cover the specific WHHP-EWH system tested. A generalized test procedure for other new innovations or combination to other sizes of storage tanks would require an extension of this work.

\section{DEFINITIONS}

\section{Water-Heating Heat Pump}

A WHHP is a free-standing heat pump system designed to heat water in an external water heater storage tank.

\section{Temperature-Sensitive Water Flow Control Valve}

A temperature-sensitive water FCV is a valve designed to regulate the flow rate of water circulating about the condenser. The FCV acts to control the minimum temperature of water flowing to the WH from the WHHP.

\section{First Pass}

The first pass is the portion of a recovery test of a WHHP-EWH system from the beginning of the recovery test, until the time when the FCV opens above its minimum discharge temperature or the equivalent FCV is manually opened.

\section{Latter Passes}

Latter passes are the portion of a recovery test of a WHHP-EWH system from the termination of the first pass until the end of the recovery test,

\section{TEST METHOD - PROPOSED MODIFICATIONS}

This section describes modifications to Reference 2, "Uniform Test Method for Measuring the Energy Consumption of Water Heaters," necessary to expand coverage of that method to include a test method for the WHHP system investigated in this study. Except as noted, all mention of particular section numbers refer to sections in Reference 2 .

\section{Installation (Section 2.1)}

Insta11 the WHHP and the 50-gallon EWH in a test room. The EWH should be installed according to Section 2.1. In accordance with manufacturer's installation instructions, the electric heating elements of the EWH should be deactivated. 
The WHHP should be placed in the vicinity of the EWH. The water connections between the WHHP and EWH, and the FCV installation should be made in accordance with the manufacturer's instructions. If the FCV is not adjustable and cannot be set according to the requirement, then an equivalent FCV may be used. The equivalent FCV system is shown schematically in figure 1. The flow control system should be constructed of material compatible with the water connection between the WHHP and EWH.

The control wires of the WHHP should be connected to the thermostat of the EWH according to the manufacturer's instructions. The power lines of the WHHP should also be connected according to the manufacturer's instructions.

\section{Test Room}

The test room should be sufficient in size and capacity to provide an unimpaired operation for the WHHP-EWH system, and to provide the ambient temperature and relative humidity specified.

\section{Thermocouple Installation - Interior (Section 2.5)}

The portion of Section 2.5 concerning the installation of the interior thermocouples is applicable with the addition of the provision that at least the two uppermost thermocouples should not be installed in line with the WH return line inlet.

In order to determine the FCV setting, additional thermocouples should be installed as follows:

\section{a. WHHP Inlet}

A thermocouple should be installed in the water line between the EWH and the WHHP inlet in order to measure the WHHP inlet temperature. The thermocouple should be positioned in such a way that it is as close to the center line of the pipe or the hose as practicable. The thermocouple should be installed as near to the EWH as practicable.

\section{b. WHHP Outlet}

A thermocouple should be installed in the water line between the EWH and the WHHP outlet. The thermocouple should be positioned in such a way that it is as close to the center line of the pipe or hose as practicable. In case heated water from the WHHP returns to the EWH via the EWH hot water outlet, then the thermocouple should be installed as near to the EWH as practicable; otherwise it may be installed anywhere along the pipe.

\section{Thermocouple Installation - Test Room (Section 2.5)}

The portion of Section 2.5 concerning the installation of a test room thermocouple is applicable with the addition of the provision that the test room thermocouple should be shielded against the air current originating from the 
WHHP. The test room thermocouple should also be kept away from the water line connections between the WHHP and the EWH. Further, the test room thermocouple should be kept away from any air currents from the heat pump evaporator and the heating coils of the test room's heating and cooling units if such units are installed.

\section{Test Room Ambient Temperature (Section 2.8)}

The ambient air temperature of the room should be maintained at $75^{\circ} \mathrm{F}+3^{\circ} \mathrm{F}$ at all times during the test. The test room ambient temperature should be taken periodically at intervals no greater than 15 minutes throughout the duration of the test.

\section{Test Room Relative Humidity (new section)}

Maintain the relative humidity of the test room between 40 and 60 percent. Relative humidity to be measured periodically at intervals no greater than 15 minutes throughout the duration of the test.

7. Setting the Tank Thermostat (Section 2.6)

In setting the tank thermostat, the procedure given in section 2.6 is applicable when amended by the proposed changes described in Reference 1 (i.e., $145^{\circ} \mathrm{F} \pm 5^{\circ} \mathrm{F}$ ).

\section{Water Supply (Section 2.3)}

The procedures described in Section 2.3 are applicable when amended by the proposed changes described in Reference 1 (i.e., $53^{\circ} \mathrm{F}$ to $57^{\circ} \mathrm{F}$ ).

9. Setting the Flow Control Valve (new section)

The recovery test of the WHHP-EWH is divided into two sequential phases. The first phase -- called first pass -- lasts from the beginning of the recovery test until the time when the FCV or its equivalent begins to open above its minimum discharge temperature. The second phase -- called latter passes -lasts from the end of the first pass until the end of the recovery test. To ensure that the FCV or its equivalent is set correctly, the following procedure should be observed:

Instal1 WHHP with a ENH according to Section III.1 and initiate a recovery test.

\section{a. WHHP Equipped With a FCV Having a Fixed Non-Adjustable Setting}

Ascertain that the FCV setting is at least $60^{\circ} \mathrm{F}$ above the inlet temperature of the supply water. If not, the WHHP should be installed with a flow control system according to Section III.1 at the outlet of the heat pump. 
A recovery test should be started with bypass Valve 3 fully closed so that the heated water passes through the needle valve. The heat pump inlet and outlet water temperature should be monitored and the needle valve adjusted so that the temperature rise, $\Delta \mathrm{T}_{\mathrm{HP}}$, is $60^{\circ} \mathrm{F}$ during the first pass. Valve 3 should be opened fully for the latter passes.

b. WHHP Equipped With an Adjustable FCV

Monitor the water temperature at the WHHP inlet (THPI) continuously or at least once a minute. Determine whether the FCV is fully open at the time when $\mathrm{T}_{\mathrm{HPI}}$ is at least $60^{\circ} \mathrm{F}$ or more higher than the water supply temperature. If the FCV does not open fully at that time, drain the heated water from the water heater, adjust the FCV setting and restart the recovery test. This procedure should be repeated until the FCV fully opens at a time when $\mathrm{T}_{\mathrm{HPI}}$ reaches a value $60^{\circ} \mathrm{F}$ higher than the water supply temperature.

The condition of the FCV should be determined by monitoring the WHHP temperature rise, $\Delta \mathrm{T}_{\mathrm{HP}}$ (i.e., the WHHP outlet water temperature, $\mathrm{T}_{\mathrm{HPO}}$, minus the WHHP inlet water temperature, $\mathrm{T}_{\mathrm{HPI}}$ ). The $\mathrm{FCV}$ is considered open if the 5-minute moving average of $\Delta \mathrm{T}_{\mathrm{HP}}$ decreases to a quarter of its initial ( 1 st pass) value within 10 minutes of the time when $\mathrm{T}_{\mathrm{HPI}}$ first exceeds $60^{\circ} \mathrm{F}$ above the initial supply water temperature. The FCV is considered as open properly if, after $\Delta \mathrm{T}_{\mathrm{HP}}$ has reduced to less than a quarter of its initial value, $\Delta \mathrm{T}_{\mathrm{HP}}$ remains less than a quarter of its initial value for the remainder of the test.

\section{Recovery Efficiency (Section 4.1)}

Install the WHHP with a 50-gallon EWH according to the procedures given in Section III.1 and adjust the FCV according to Section III.9. The resistance heating elements should be deactivated and the recovery test performed according to the test method as amended by the proposed amendment given in Reference 1 except for the WHHP-EWH system using an equivalent flow control device for flow rate regulation.

For the WHHP-EWH system using an equivalent flow control device, the needle valve should be adjusted according to Section III.9 and then perform the recovery test as described above. The heat pump inlet and outlet water temperatures should be monitored at one-minute intervals. When $\mathrm{T}_{\mathrm{HPI}}$ reaches a temperature $60^{\circ} \mathrm{F}$ higher than the supply water temperature, the shut off valve should be opened fully so that $\Delta \mathrm{T}_{\mathrm{HP}}$ decreases to less than 25 percent of its initial value. The temperature rise, $\Delta \mathrm{T}_{\mathrm{HP}}$, should then remain at this level for the remainder of the recovery test. If either $\mathrm{T}_{\mathrm{HPI}}$ or $\mathrm{T}_{\mathrm{HPO}}$ exhibit a fluctuation, the 5-minute moving averages of the temperatures should be used instead of the individual measured temperatures:

11. Standby Loss (Section 3.4)

The system of the WHHP coupled with a 50-gallon EWH should be installed according to Section III.1. The resistance type heating elements should be deactivated and a normal operation should be established within the mean tank temperature 
limits specified in Reference 1, For the system using an equivalent flow control system, the shut-off valve should be fully open (Valve 2, figure 1). Perform a standby loss test according to Reference 1 and as revised by the proposed amendments in Reference 4.

The standby loss of the system, S, should be calculated as follows:

$$
\mathrm{S}=\frac{\mathrm{Z}_{\mathrm{s}} \times 3412}{\mathrm{k} \times \mathrm{V} \times \Delta \mathrm{T}_{3} \times t}-\frac{\Delta \mathrm{T}_{4}}{\Delta \mathrm{T}_{3} \times \mathrm{t} \times \mathrm{E}_{\mathrm{r} 2}}
$$

where $E_{r 2}$ = the recovery efficiency of the WHHP during the latter passes as measured according to the procedure given in the next section.

All other terms are as described in Reference 2.

12. Recovery Efficiency of Latter Passes (new section)

Initiate a recovery test and record the mean tank temperature and the cumulative energy flow to the WHHP at the beginning and at the end of the latter passes. The recovery efficiency of latter passes, $\mathrm{E}_{\mathrm{r} 2}$, is calculated as:

$$
E_{r 2}=\frac{k \times V \times\left(T_{f}-T_{F C V}\right)}{Z_{r 2} \times 3412}
$$

where $\mathrm{Z}_{\mathrm{r} 2}=$ total electrical energy flow to the WHHP during the latter passes, determined in accordance with section 3.2.3 (in Reference 1) in $\mathrm{kWh}$.

$\mathrm{T}_{\mathrm{f}}=$ final mean tank temperature, measured in accordance with Section 3.6 in ${ }^{\circ} \mathrm{F}$.

$\mathrm{T}_{\mathrm{FCV}}=$ mean tank temperature at the time the FCV opens, measured in accordance with section 3.6 in ${ }^{\circ} \mathrm{F}$.

13. Power Input Determination (Section 3.2)

The power input should be determined in accordance with the proposed procedure of Section 3.2 of Reference 1 .

IV. RATIONALE AND COMMENTS FOR TEST METHODS AND PROCEDURES USED

1. Installation

The resistance heating elements were deactivated according to the manufacturer's instructions for the WHHP investigated here. Operation of the resistance heating elements would reduce the effective efficiency of the WHHP-WH system. 
The performance of the system is a function of the FCV setting as shown in Section V; therefore the system should be tested under the same FCV control or equivalent conditions. A fair way of dealing with this in a general test procedure has not been established.

\section{Test Room}

The selection of a narrow ambient temperature with fluctuation allowed only within this range will minimize errors in testing. These limits do not necessarily require an environmental chamber for testing but will require a conditioned and controlled laboratory space.

\section{Thermocouple Installation - Interior}

The current test method requires that the thermocouples installed to measure the mear water temperature be positioned as far as possible from any obstructions such as the heating element, anodic protective device, or a water tank or flue wall.

The interior thermocouples should be installed so that they measure the mean tank temperature accurately, and are not affected by the stream of heated water returning from the WHHP.

One additional thermocouple is required for tests with the WHHP equipped with a FCV which requires adjustment under Section III.9. The additional thermocouple is installed in the inlet line to the WHHP for measuring $\mathrm{T}_{\mathrm{HPI}}$.

If the WH hot water outlet pipe thermocouple can not be used to measure $\mathrm{T}_{\mathrm{HPO}}$, a thermocouple should be installed in the outlet line of the WHHP.

\section{Thermocouple Installation - Test Room}

The current test method requires that the test room thermocouple be shielded against direct radiation from the water heater. The WHHP also generates convective air currents around the water heater because of the evaporator fan; therefore, the test room thermocouple should also be shielded against this convective air current.

\section{Test Room Ambient Temperature}

Tests conducted on the electric HPWH indicate that both the standby loss and the recovery efficiency are affected by the variation of the room ambient temperature. Therefore, the room ambient temperature should not be allowed to vary over too wide a range. HPWH data indicate that this effect can change recovery efficiency $\left(E_{R}\right)$ by one percentage point in the measured value per Fahrenheit degree (dry bulb).

Test data presented in Section $\mathrm{V}$ indicate that an average ambient air temperature within a range of $75^{\circ} \mathrm{F} \pm 3^{\circ} \mathrm{F}$ is required in order to maintain the average daily energy consumption, $C_{y}$, with \pm 2 percent of its value at $75^{\circ} \mathrm{F}$. 


\section{Test Room Relative Humidity}

Tests conducted at NBS on the electric HPWH indicate that, in general, over the specified room ambient air temperature range, variations of 40 to 60 percent relative humidity do not appreciably affect HPWH operation. However, high humidity conditions do tend to improve the system efficiency.

\section{Setting the Tank Thermostat}

Water heater thermostats are normally factory-set at $140^{\circ} \mathrm{F}$ for gas and at $150^{\circ} \mathrm{F}$ for electric WH. DOE uses the average value of the two common factory settings of WH thermostats. Since NBS has determined that the national average water supply temperature is $55^{\circ} \mathrm{F}$, the difference between these two temperatures, $90^{\circ} \mathrm{F}$, is the required water temperature rise in the current test method, The $55^{\circ} \mathrm{F}$ supply water temperature is now proposed for the electric HPWH and the WHHP. With a required water temperature rise of $90^{\circ} \mathrm{F}$, the tank thermostat setting is specified at $145^{\circ} \mathrm{F}$.

The mean tank temperature after initial cutout, therefore, should be $145^{\circ} \mathrm{F} \pm 5^{\circ} \mathrm{F}$ to maintain the same temperature differential and tolerance as in the current test method.

\section{Water Supply}

The National Bureau of Standards has determined that the national average water supply temperature is $55^{\circ} \mathrm{F}$. The current test method specifies a $70^{\circ} \mathrm{F}$ supply water temperature for the reason that a $70^{\circ} \mathrm{F}$ supply water temperature is less burdensome to obtain for use in the testing of WH. Furthermore, for the general types of gas, oil, or electric storage type WH, the supply water temperature has a negligible effect on the determination of the water heater's recovery efficiency. For most testing facilities, climatic conditions or other factors are such that for all or part of the year water supply temperatures exceed $55^{\circ} \mathrm{F}$. Therefore, if a $55^{\circ} \mathrm{F}$ supply water temperature were specified in the current test method, these facilities would have an added cost of equipment and testing time to cool the available supply water prior to conducting a test.

Using the same $70^{\circ} \mathrm{F}$ supply water temperature with a $90^{\circ} \mathrm{F}$ temperature rise for testing of an electric HPWP or WHHP, however, imposes a penalty on the recovery efficiency for this type of WH. This is due to the fact that the heat pump works more efficiently at a lower condenser temperature for the same evaporator temperature (room tempenature). A $55^{\circ} \mathrm{F}$ supply water temperature, therefore, is specified for the electric HPWP as well as the WHHP.

Furthermore, in order to establish the same tolerance for variation as in the current test method, the water supply temperature to the electric HPWH and WHHP inlet is required to be maintained between $53^{\circ} \mathrm{F}$ and $57^{\circ} \mathrm{F}$.

\section{Setting the Flow Control Valve (FCV)}

Tests described in Section $V$ indicate that the recovery efficiency of the system is a function of the FCV setting. With the WHHP used in these tests, the FCV 
setting of $115^{\circ} \mathrm{F}$ offers the highest heated water tempeature during the first pass without significantly adversely affecting the recovery efficiency.
a.
WHHP Equipped with an FCV Having a Fixed Non-Adjustable Setting
The FCV should act to control WHHP outlet temperatures to a minimum temperature rise of $60^{\circ} \mathrm{F}$, thus preserving a high degree of stratification in the storage tank. If, when the flow control valve opens $\Delta \mathrm{T}_{\mathrm{HP}}$ is less than $60^{\circ} \mathrm{F}$, the adjustment of the first pass flow rate may be achieved by using either the equivalent flow control system (figure 1 ) or by mon- itoring the heating rate. For a given working condition, the WHHP has a constant heating capacity. This means a smaller flow rate gives a higher temperature rise and vice versa. The adjustment of the needle valve is needed to give a temperature rise of $60^{\circ} \mathrm{F}$ above the $55^{\circ} \mathrm{F} \pm 2^{\circ} \mathrm{F}$ supply water temperature.

\section{b. WHHP Equipped With an Adjustable FCV}

The opening of the FCV may be identified by changes in various measured parameters such as the sudden increase of flow rate observable via an inline flow meter; the beginning of an increase in the average power input; the end of the slight cyclic fluctuation in the WHHP outlet water temperature; and the end of the cyclic fluctuation in input power. Several of these indicators might be used to identify the opening of a FCV, but some might be difficult to interpret. The increase of the water WHHP inlet and outlet temperatures and the concurrent decrease of the temperature rise between the same outlet and inlet, however, are unmistakable. As explained in Section V, the opening of the FCV is not a sudden and abrupt action. Therefore, the FCV is considered open if, after the WHHP inlet temperature has risen substantially, the temperature rise between the WHHP outlet and inlet temperature decreases substantially.

\section{Recovery Efficiency}

As discussed previously, the recovery efficiency is a function of the FCV setting. Experiments discussed in Section $v$ indicate that a FCV setting of $115^{\circ} \mathrm{F}$ for the WHHP used in this evaluation gives the hottest water with one pass without degrading the efficiency significantly. In these tests, the resistance type heating elements were deactivated. Ideally, the WHHP-WH system would be sized such that the electric elements are not needed. A fair way of dealing with this in a general test procedure has not been established.

\section{Standby Loss}

During the standby operation of the system the WHHP operates at a temperature range higher than the FCV setting; therefore, in case an equivalent flow control system is used, it should be arranged to allow full flow. For the same reason, the WHHP has a higher inlet water temperature and operates at a lower recovery efficiency. To reflect this fact in the calculation of the standby loss, a 
different recovery efficiency is used in the equation. This recovery efficiency called the recovery efficiency of latter passes and denoted by the symbol $\mathrm{E}_{\mathrm{r} 2}-$ is used in the standby loss calculation.

The general way to handle standby loss is not resolved for several reasons, including the validity of modifying a unit, the size of tank and its characteristics, and details of the WHHP to WH hookup.

\section{Recovery Efficiency of Latter Passes}

This recovery efficiency may be obtained with no additional testing. It provides a more realistic calculation of the actual operation of standby loss.

\section{Power Input Determination}

One major difference between the EWH with immersed resistance type heating elements and the electric HPWH and WHH is in the power output variability per unit of power input. The former operate at a constant power input when energized the latter operates at variable power input when the heat pump is energized. The amount of energy an electric HPWH and WHHP consumes depends strongly on its operating conditions.

The average input power, as such, must be determined in the recovery test as 3 time-averaged energy input over the duration of the recovery test. Therefore, in the recovery test, the amount of electrical energy consumed must be determined along with the duration of the recovery test. The average power in kilowatts (kW) is determined as the ratio of energy used $\left(Z_{r}\right)$ in $k W h$ to the time of the recovery test $\left(t_{r}\right)$ in hours.

\section{LABORATORY TEST PROGRAM}

\section{Introduction}

This section summarizes the test program done in support of the modifications proposed in this report. It reports the results of laboratory studies of a WHHP having a water FCV when coupled with a 50-gallon EWH. The purpose of this work was to identify those operating characteristics and features of the WHHP which must be addressed in modifying the existing DOE water heater test procedures to accommodate this class of devices. It should be noted that the results obtained and reported herein were for an EWH with specific volume, water inlet-outlet configuration and water storage tank insulation. Performance of a WHHP system is dependent on water heater capacity and design and will be different for other WHHP-WH combinations.

\section{System Description}

The WHHP system is comprised of a WHHP unit, including a FCV, and a water storage tank (typically an existing EWH). A detalled description of each of these components follows. 


\subsection{Water Heating Heat Pump}

The WHHP used in this investigation is packaged in an enclosure, $0.46 \mathrm{~m}$ in height, $0.46 \mathrm{~m}$ in width, $0.36 \mathrm{~m}$ in depth (18 in $\mathrm{x} 18$ in $x 14$ in). Air is blown over the evaporator coil by the fan while water is circulated from the bottom drain valve of the hot water storage tank, through the refrigerant-to-water condenser, and back to the hot water outlet of the storage tank by the water pump.

The WHHP is designed as an add-on (or retrofit) to any existing WH. Although similar to the integral HPWH described in Reference 1, a basic difference exists between the two. This difference is in the interface between the refrigerant condenser and the stored hot water. The HPWH condenser is submerged in the WH storage tank. The water-side heat transfer is governed by natural convection that occurs between the coil and the surrounding water. In the case of the WHHP, heat transfer is via a refrigerant-to-water heat exchanger located external to the storage tank. The water-side heat transfer is governed by forced convection. Further, the condenser of the HPWH operates against a water temperature averaged over the height of the condenser coil. The condenser of the WHHP, on the other hand, operates against the water temperature at the bottom of the storage tank. This difference makes the WHHP more susceptible to stratification in the storage tank than the HPWH. In order to maintain a high degree of stratification for a good portion of the recovery phase, a thermostatic FCV is used in the hot water outlet of this WHHP unit.

\subsection{Water Heater}

The WH used in the current tests was a 50-gallon EWH; it is shown schematically in figure 1. The WH was originally equipped with upper and lower $4500 \mathrm{~W}$ heating elements and a thermostat for each. The heating elements were deactivated for the purpose of the current experiments and the lower thermostat was used to activate the heat pump.

The cold water inlet is located at the top of the WH. A dip-tube is installed inside the storage tank such that cold water is introduced at the bottom portion of the storage tank. The dip-tube extends from the water inlet at the top to $5.1 \mathrm{~cm}$ ( $2 \mathrm{in}$ ) above the bottom. The drain valve is located at the side of the WH $2.5 \mathrm{~cm}$ (1 in) above the bottom of the WH. The hot water outlet is located at the top of the WH.

The water connection between the WHHP and the WH is made with $1 / 2$ in copper tubing. The tubing is insulated with $1 / 2$ in polychloroprene.

To set the WH thermostat, the WH was filled with supply water and purged of any residual air. The water connection was also purged of air and the WHHP primed. The tank thermostat was set and the WHHP energized. At the thermostat cut-out, the maximum mean water heater tank temperature was measured. The thermostat was set to maintain the maximum mean tank temperature in the range of $62.8^{\circ} \mathrm{C} \pm 2.8^{\circ} \mathrm{C}$ $\left(145^{\circ} \mathrm{F} \pm 5^{\circ} \mathrm{F}\right)$. If the maximum mean tank temperature was not within this range the above procedure was repeated until the requirements were met. 


\subsection{Flow Control Valve (FCV)}

Since the heating capacity of the heat pump at a given working condition is constant, the temperature rise of the water passing through the condenser is inversely proportional to the volume flow rate. To maintain a high heat pump water outlet temperature so that cold water is not introduced into the top of the water storage tank, a thermostatic FCV is utilized. The FCV is located at the outlet of the heat pump as shown in figure 1. The function of the FCV is to restrict the flow of water through the condenser when inlet water temperatures are low, while allowing full water flow for high inlet water temperatures. The FCV restricted the flow rate to approximately $0.01 \mathrm{~L} / \mathrm{s}(0.15 \mathrm{gpm})$ at the minimum outlet water temperature of $46.1^{\circ} \mathrm{C}\left(115^{\circ} \mathrm{F}\right)$. The FCV opened completely and allowed the circulating pump to maintain a flow rate of $0.10 \mathrm{~L} / \mathrm{s}$ ( $1.5 \mathrm{gpm}$ ) when the inlet water temperature to the heat pump heat exchanger exceeded $46.1^{\circ} \mathrm{C}$ $\left(115^{\circ} \mathrm{F}\right)$.

With the FCV restricting the heat exchanger outlet temperature to $46.1^{\circ} \mathrm{C}\left(115^{\circ} \mathrm{F}\right)$ the temperature rise is designed to be approxiamtely $33^{\circ} \mathrm{C}\left(60^{\circ} \mathrm{F}\right)$ for the first pass through the heat pump with an inlet temperature of $12.8^{\circ} \mathrm{C}\left(55^{\circ} \mathrm{F}\right)$ and a flow rate of $0.01 \mathrm{~L} / \mathrm{s}(0.15 \mathrm{gpm})$. The low flow rate allowed the stratification in the water heater to be maintained.

\section{Test Facilities and Instrumentation}

\subsection{Environmental Chamber}

To perform tests at closely controlled ambient temperature, the WHHP system was installed inside an environmental chamber. During the recovery experiments, the WHHP is an approximately constant cooling load for the environmental chamber while the water storage tank is an increasing heating load. During the standby tests, the heat pump is a cyclic cooling load on the enviornmental chamber, while the water heater is an approximately constant heating load. As a result, the environmental chamber responded differently to a standby test and to a recovery test.

In order to maintain approximately the same average ambient air temperature for the different tests, a preliminary test was conducted at a desired condition and the average ambient temperature calculated and correlated with the temperature set point of the environmental chamber. To measure the ambient temperature, a shielded thermocouple was installed $0.61 \mathrm{~m}$ (2 ft) from the water heater and WHHP at a level midway between the top and bottom of the water heater.

\subsection{Instrumentation}

Six thermocouples were placed inside the storage tank of the water heater along a line parallel to the axis of the cylindrical storage tank, each measuring one sixth of the water volume (see figure 1). The thermal energy content of the water was computed from the average of the six thermocouples. Thermocouples were also installed at the inlet and outlet of the water heater to measure water tem?eratures during draw tests. 
The temperature of water entering the WHHP was measured with a thermocouple at the inlet to the WHHP. Similarly, the thermocouple at the outlet of the heat pump measured the temperature of water exiting from the WHHP. The temperature difference of the two thermocouples gives the temperature rise generated by the WHHP during periods of WHHP operation.

A watt meter was used to measure the power consumption of the WHHP. A watthour meter with digital output was used to measure the cumulative energy consumption.

\subsection{Water Supply System}

In order to maintain an inlet water temperature of $21.8^{\circ} \mathrm{C}\left(55^{\circ} \mathrm{F}\right)$ as specified in the test procedure, the city water (usually warmer than $55^{\circ} \mathrm{F}$ during the course of the tests) was mixed with ice water via a mixing valve before entering the water heater. During draw tests, three different flow rates were selected by opening the appropriate solenoid valve/flow rate branches shown in figure 2 . Valve operation was controlled by a microprocessor, which opened and closed valves at preprogrammed times.

\subsection{Data Acquisition}

The data acquisition system included a datalogger and a digital recorder/printer, as shown schematically in figure 3. The sensors included 11 thermocouples, a watt meter and a watt-hour meter. The datalogger scanned all sensors at 5-minute intervals during non-draw periods. During draw tests at predetermined times, the microprocessor opened one or more of the three solenoid valves to allow supply water to flow into the water heater and the heated water to flow out of the water heater. Concurrently, the microprocessor sent an alarm signal to the datalogger and also turned on the supply water pump. When an alarm signal was received by the datalogger, the datalogger changed its mode of operation. The second mode of operation allowed the datalogger to scan the sensors at 10-second intervals. At the termination of a draw, the microprocessor turned off the alarm signal. The termination of the alarm signal causes the datalogger to revert back to the regular mode of operation, scanning sensors at 5-minute intervals, and turning the supply water pump off.

Data scanned by the datalogger were recorded on cassette tape and simultaneously printed for purposes of on-site monitoring. For data processing, the cassette tape data were transmitted to the NBS UNIVAC 1108 main frame computer.

\section{Tests and Results}

Five different types of experiments were performed: 1) recovery, 2) standby, 3) draw, 4) recovery at different FCV settings, and 5) water heater cooldown. The water heater tests were conducted under conditions specified in the test method of Reference 2 where appropriate.

\subsection{Recovery Tests}

In preparing for the recovery tests, the WHHP was turned off. The residual air was eliminated from the WH, and the tubes between the WH and the WHHP were filled 
with water and purged of air. The WH was filled with supply water at an average temperature slightly lower than $12.8^{\circ} \mathrm{C}\left(55^{\circ} \mathrm{F}\right)$. The data acquisition system was started when the average water temperature inside the WH was approximately constant. The WHHP was also started. The heat pump operated until the average water temperature in the WH reached a value of $62.8^{\circ} \mathrm{C}\left(145^{\circ} \mathrm{F}\right)$. At that temperature, the thermostat acted to cut out the heat pump. After the final set of data was recorded, the data acquisition system was turned off.

Test results for a typical recovery test are shown in figures 4 through 7 . In figure 4, the temperature recordings of the six thermocouples inside the WH are plotted with respect to the elapsed time of test. As seen in figure 4, after the inception of the recovery test, the water at the bottom of the WH was pumped through the WHHP for the first time (the first pass), causing the water temperature at the top of the tank as measured by thermocouple 1 (TC1) to rise, A temperature rise of $34^{\circ} \mathrm{C}\left(61^{\circ} \mathrm{F}\right)$ above the water temperature at the bottom of the tank was measured. As the heated water accumulates at the top of the tank, the hot/cold water interface descends towards the bottom of the tank in a piston-like manner. The first pass is completed when the front reaches the bottom of the storage tank. The distinct stratification layers during the first pass are quite evident. For example, at an elapsed time of 30 minutes, TC3 through TC6 were still at the supply water temperature, while TC2 was at $42^{\circ} \mathrm{C}$ and $\mathrm{TC} 1$ at $47^{\circ} \mathrm{C}$. This meant there was very little mixing of heated water with cold water - due in part to the low flow rate caused by FCV throttling. Furthermore, the whole tankful of water was heated in the first pass, in a uniform manner. This is demonstrated by the similarity of the heating curve of the six thermocouple temperature tracings in the first pass.

After the temperature interface reaches the bottom, the warmed water is heated further (through latter passes) by the WHHP, causing the FCV to open, resulting in the maximum water flow rate. As a result of the high flow rate, the temperature rise in the latter passes is reduced. The high flow rate causes some mixing as can be seen at the latter part of the recovery test in figure 4 (the temperature tracings become almost parallel).

The average water temperature was plotted in figure 5 for comparison with the power of the WHHP and the ambient temperature. The average water temperature increases monotonically with respect to the elapsed time. The ambient temperature shows some fluctuations within a narrow range.

The power curve may be divided into two portions, the first pass portion and the latter passes portion. The first pass portion lasted from the beginning of the test until 110 minutes. The latter passes portion lasted from the end of the first pass until the end of the recovery test. The first pass portion of the power curve is distinguished by a small fluctuation. The fluctuation was caused by the action of the temperature-sensitive FCV. When the water exiting the WHHP (and entering the FCV) is at a low temperature, the FCV closes to allow the minimum flow rate. This small flow rate causes the incoming water to be heated to a higher temperature by the WHHP. The warmer water causes the FCV to increase its opening causing a higher flow rate. The higher flow rate, in turn, produces a lower outlet water temperature. The relative colder outlet water causes the FCV to close to its smallest opening. This sequence of events repeates itself again and again 
until the temperature of the WHHP outlet water rises above the FCV setting. The cyclic action of the FCV causes a fluctuating load on the heat pump compressor and water pump which is reflected in the fluctuation of the power curve $\rho f$ figure 5. After the first pass, the FCV opens fully and the power curve no longer fluctuates but continues to increase with WHHP inlet water temperature which establishes the heat pump condenser temperature.

The inlet water and outlet water temperatures of the WHHP are plotted in figure 6 . The inlet temperature remains constant during the major portion of the first pass. During the latter portion of the first pass, the warm front approaches the bottom of the storage tank causing the inlet water to increase. The outlet water temperature in the first pass fluctuates as discussed previously. During the first pass, the temperature rise is $35^{\circ} \mathrm{C}\left(63^{\circ} \mathrm{F}\right)$. The temperature rise after the first pass is about $7^{\circ} \mathrm{C}\left(13^{\circ} \mathrm{F}\right)$.

The recovery tests are summarized in table 1 . They are plotted in figure 7 as a function of ambient air temperature. In the range of interest, the recovery efficiency increases as the ambient temperature increases. The recovery efficiency for the WHHP tested is interpolated to be 2.32 at an ambient temperature of $75^{\circ} \mathrm{F}$.

\subsection{Standby Tests}

The standby test is a static test performed to determine the energy required to maintain the stored water at some temperature above ambient. For this test, the WH was filled with supply water, residual air was eliminated, and the connection pipes between the WH and the WHHP were purged of air. The WHHP was primed and then turned on. The system was continuously monitored until the average water temperature in the storage tank almost reached the cutout point. At this time, the data acquisition system was turned on and the standby test started. During the standby test, all the sensors were scanned and recorded at 10-minute intervals. The standby tests lasted 60 hours. If, at the end of 60 hours, the WHHP was operating, the standby test was continued until the WHHP cut out.

Results for a typical standby test are shown in figures 8 through 10 . In figure 8 , the temperatures of the six WH thermocouples and average of the six are shown as a function of time. The curves show the typically cyclic nature of a WH standby test curve. At a water temperature controlled by the thermostat upper limit, the thermostat cuts out the WHHP causing the WH to go into a cooldown. phase. In the cooldown phase of $\mathrm{WH}$ operation, the average water temperature decreases in an exponential fashion [1]. When the water temperature decreases to a level below the thermostat lower limit, the thermostat triggers the WHHP to operate, causing the water temperatures to increase rapidly.

In figure 9, the average wH temperature is plotted for comparison with the ambient air temperature and the heat pump power. As shown, the average water temperature starts at $64.5^{\circ} \mathrm{C}\left(148.1^{\circ} \mathrm{F}\right)$ then follows five cycles of heat pump on and heat pump off. The peak average water temperature for each of the cycles remains approximately the same, $62^{\circ} \mathrm{C}\left(143.6^{\circ} \mathrm{F}\right)$. The mean average water temperature for the entire duration of the standby test is $59.9^{\circ} \mathrm{C}\left(139.8^{\circ} \mathrm{F}\right)$. The ambient temperature averaged $27.5^{\circ} \mathrm{C}$ $\left(81.5^{\circ} \mathrm{F}\right)$. The power is plotted at the bottom of figure 9. There are spikes of short duration coinciding with periods in which the average water temperature is restored to the maximum stored water temperature. 
The standby tests are summarized in table 2 and plotted in figure 10. In the range of interest, the standby loss decreases almost linearly as the average ambient temperature increases. The standby loss is interpolated to be about 1.24 percent per hour at an ambient temperature of $24^{\circ} \mathrm{C}\left(75^{\circ} \mathrm{F}\right)$.

\subsection{Draw Tests}

The draw tests were performed to measure the energy consumption of the system under simulated draw conditions. Each draw test lasted at least 24 hours. The draw schedule for a 24-hour period is the same as the one used in Reference 1 and is reproduced in table 3 . In table 3 the first column gives the beginning and the end of an individual draw. The second column gives the volume of the individual draw as a fraction of the total draw volume. The total draw volume is designed to be $243 \mathrm{~L}$ ( 64.3 gallons).

The water supply temperature was measured by the thermocouple installed at the inlet to the WH and was adjusted as close to $12.8^{\circ} \mathrm{C}\left(55^{\circ} \mathrm{F}\right)$ as possible. Preliminary draw tests were conducted to correlate the setting of the mixing valve (figure 2) with the measured average water supply temperature.

Temperature during a typical draw test is shown in figures 11 and 12 . In figure 11, the temperature recordings of the six thermocouples inside the WH are plotted with respect to the elapsed time of test. Since the water supply entered the water heater at the bottom, the water temperature at the bottom (TC6) showed the largest variation as a function of the draw. This is clearly demonstrated in figure 11; for example, at an elapsed time around 700 minutes, there were a series of draws (draws 非12 through 非7 in table 3) causing TC6 to fluctuate between $40^{\circ} \mathrm{C}$ and $20^{\circ} \mathrm{C}$. TC6 increased sharply after four draws (draw 非14 through 非17) due to the operation of the heat pump. During the same time period the temperature at TC5 changed very little.

It should be noted that TC1 decreases a little more than TC2 due to draws. This was because the concurrent operation of the WHHP causes tempering of the hot water at the top of the WH by the WHHP outlet water temperature controlled by the FCV. In fact, the tempering showed up several times after relatively heavy draws causing TCI to drop below TC2.

The average $\mathrm{WH}$ temperature and the ambient temperature were plotted in figure 12. Again the sharp decreases in average temperature were due to relatively heavy draws, and the increases in temperature were always because of the operation of the WHHP. The ambient temperature fluctuated within a narrow range.

\subsection{Recovery Tests at Different FCV Settings}

Recovery tests at FCV settings differ from the manufacturer's setting of $46.1^{\circ} \mathrm{C}\left(115^{\circ} \mathrm{F}\right)$ were conducted to determine the effects of the FCV on the WHHPEWH system performance. The results are shown in figures 13-16. 
One recovery test was conducted without the restriction of the FCV, allowing a full flow of $0.1 \mathrm{~L} / \mathrm{s}(1.5 \mathrm{gpm})$ to be maintained by the circulation pump for all passes including the first. To do this, Valves 1 and 2 in figure 1 were closed and Valve 3 was fully open. The temperature versus time variations for this run are shown in figure 13.

For the recovery test conducted with the FCV removed, flow between the water heater and the heat pump was unrestricted, resulting in a constant flow rate of $1.5 \mathrm{gpm}$. The six temperature versus time curves for this recovery test are shown in figure 13. Although the stratification in the water heater is minimized relative to that in a recovery test with FCV operating, it can still be seen that 30 minutes elapsed before the temperature at the bottom of the tank increased. The sloping parallelism of the temperature curves during the first 30 minutes indicates a significant degree of mixing of the stored water induced by the higher flow rate.

A major difference of the two systems is reflected in the temperature recordings. This difference is the availability of heated water shortly after a recovery mode is started. Specifically, the system with a FCV produced a temperature rise of $32^{\circ} \mathrm{C}$ at TC1 in about 30 minutes (figure 4 ), which means at least $1 / 2$ tank of water has been heated to $46.1^{\circ} \mathrm{C}\left(115^{\circ} \mathrm{F}\right)$. In the same 30 minutes, the system without the FCV (figure 15) produced a temperature rise of only about $9^{\circ} \mathrm{C}$.

Additional recovery tests at different FCV settings were performed by manual control. This was done by closing Valve 1 and Valve 3 while keeping Valve 2 open causing water to flow through the needle valve. The needle valve was adjusted so the outlet water temperature would be the same as for a regular recovery test using FCV during the first pass. The WHHP outlet water temperature was monitored continuously. Valve 3 was manually opened when the heat pump outlet water temperature reached the desired level after the first pass. Tank temperatures for a recovery test with the FCV setting at $48.3^{\circ} \mathrm{C}\left(119^{\circ} \mathrm{F}\right)$ are shown in figure 14. Figure 15 shows the water temperature variation at the WHHP inlet and outlet for a FCV setting of $48.3^{\circ} \mathrm{C}\left(119^{\circ} \mathrm{F}\right)$. A slight overshoot, due to manual control of the globe valve, is indicated on the completion of the first pass. The oscillatory variation of the WHHP outlet temperature that is characteristic of the action of a FCV is not evident in figure 14 because of the manual flow control being used. The watt-hour and the power curves are similar to those of the regular recovery test, except for the lack of any significant oscillatory motion in the first pass portion of the power curve.

The recovery efficiency, $E_{r}$, plotted in figure 16 as a function of the FCV setting shows that $E_{r}$ for this unit is approximately a constant for FCV settings, perhaps decreasing slightly for higher settings.

\subsection{Water Heater Cooldown Tests}

The standby loss, the recovery efficiency and the daily energy consumption of the WHHP-EWH system depends on the size and construction of the water heater as well as the WHHP-WH. In order to characterize the thermal performance of this particular WH, a cooldown test was performed. This test yields the WH time constant -- a measure of the water heater insulation properties and other thermal losses. 
To conduct the test, the WH was filled with supply water, purged of any residual air, and energized until the average water temperature reached a level slightly higher than $62.8^{\circ} \mathrm{C}\left(145^{\circ} \mathrm{F}\right)$. At this time, the data logger was started to monitor and record at 10-minute intervals the temperature readings of the six thermocouples inside the water heater and the one thermocouple of the ambient temperature in the environmental chamber. The cooldown test was run for 21 hours.

The results of the cool-down test are shown in figure 17, in which the average water temperature and the ambient air temperature are plotted. The WH cooldown loss can be determined by fitting the average water temperature curve to an exponential cooldown curve [1].

$$
\frac{\mathrm{Q}}{\mathrm{Q}_{0}}=\mathrm{e}^{-\mathrm{n}_{\mathrm{S}} \mathrm{t}}
$$

Here Q is the thermal energy content of the WH referred to the ambient temperature, $Q_{0}$ is the same thermal energy at the beginning of the cooldown test, and $t$ is the time elapsed of the cooldown test. The cooldown loss, $n_{S}$, is found to be $0.0199 / \mathrm{h}$. The cooldown loss is equivalent to standby loss for electric water heaters with immersed heating elements. For a WHHP system, the measured standby loss will be less than the cooldown loss because the heat pump replaces the lost energy with a coefficient of performance greater than one. A value of $2 \% / h$ for a cooldown loss is typical of EWH with fiberglass insulation.

\section{Performance Indices}

\subsection{Energy Consumption Calculations}

As discussed previously and shown in figure 10, the standby loss decreases linearly as the ambient temperature increases. As such, the standby loss may be interpolated or extrapolated for ambient temperature equal to $20.6^{\circ} \mathrm{C}\left(69^{\circ} \mathrm{F}\right)$, $23.9^{\circ} \mathrm{C}\left(75^{\circ} \mathrm{F}\right)$, and $27.2^{\circ} \mathrm{C}\left(81^{\circ} \mathrm{F}\right)$. A similar procedure may be applied to determine the recovery efficiency and average power at the three ambient temperatures. The resultant standby loss, recovery efficiency, and average power are tabulated in table 4.

Using the equation for calculating the average hourly hot water storage energy consumption, $\mathrm{c}_{\mathrm{us}}$, as given in Reference 2

$$
c_{\mathrm{us}}=\mathrm{s} \times \mathrm{k} \times \mathrm{V} \times \Delta \mathrm{T}_{6}
$$

Calculations were made for the three ambient temperatures. Results are tabulated in table 4. The daily water heater energy consumption, $C_{w h}$, was also calculated using the equation given in Reference 2:

$$
C_{w h}=\frac{k \times U \times \Delta T_{5}}{E_{r}}
$$


The average daily energy consumption, $C_{y}$, is given as a function of the storage energy consumption, water heating consumption, and power input as follows:

$$
C_{y}=\frac{1}{3412}\left[C_{w h}+c_{u s} \times\left(24-\frac{C_{w h}}{P \times 3412}\right)-J_{h}-J_{c}\right]
$$

In eq $4, J_{h}=J_{c}=0$ since no heat traps were installed in the experimental setup.

The results of these calculations are tabulated in table 4 .

The average daily energy consumption is plotted in figure 18 as a function of the ambient air temperature. It is seen that in the range of interest, the average daily energy consumption decreases in a near-linear fashion as the ambient temperature increases. If the average daily energy consumption is allowed a variation of \pm 2 percent of the value at $23.9^{\circ} \mathrm{C}\left(75^{\circ} \mathrm{F}\right)$, then the ambient temperature may be allowed to vary between $22.6^{\circ} \mathrm{C}\left(72.7^{\circ} \mathrm{F}\right)$ and $25.2^{\circ} \mathrm{C}\left(77.3^{\circ} \mathrm{F}\right)$. This result indicates that the average ambient temperature under which the system is tested may not be changed over a wide range without affecting energy consumption substantially. Too wide an ambient air temperature range may give misleading results on the merit of the system.

\subsection{Comparison Between Calculated and Measured Energy Consumption}

The energy consumption for a 24-hour draw discussed in Section 4.3 is presented in table 5. The measured daily energy consumption is $8.15 \mathrm{kWh}$ for the test, which consisted of a total draw of 64.3 gallons with an average wh inlet temperature of $12.2^{\circ} \mathrm{C}\left(54^{\circ} \mathrm{F}\right)$ and a corresponding outlet temperature of $60.0^{\circ} \mathrm{C}\left(140^{\circ} \mathrm{F}\right)$. The draw test was conducted in an ambient temperature of $24.2^{\circ} \mathrm{C}\left(75.6^{\circ} \mathrm{F}\right)$. Also reported in table 5 is the calculated average daily energy consumption under these particular water storage and draw conditions. The favorable agreement between the measured daily energy consumption and the calculated average daily energy consumption $(8.30 \mathrm{kWh} / \mathrm{day})$ indicates the validity of the test methods and the equations used for calculation for the chosen example. However, further work is needed to investigate the agreement for other WHHP sytems, such as those not having flow control valves.

\section{CONCLUSIONS}

- The standby loss of the WHHP-EWH system is approximately a linear function of the ambient air temperature over the measured range between $21^{\circ} \mathrm{C}\left(69.8^{\circ} \mathrm{F}\right)$ and $27^{\circ} \mathrm{C}\left(80.6^{\circ} \mathrm{F}\right)$. The standby loss decreases as the ambient temperature increases.

- Both the recovery efficiency and the input power of the WHHP-EWH system are linear functions of the ambient air temperature over the measured range approximately between $21^{\circ} \mathrm{C}\left(69.8^{\circ} \mathrm{F}\right)$ and $27^{\circ} \mathrm{C}\left(80.6^{\circ} \mathrm{F}\right)$. Both increase as the ambient temperature increases. 
- The water in the storage tank was heated in a highly stratified manner during the first pass of a recovery operation when the FCV or an equivalent was used. Cold supply water stayed at the bottom of the storage tank; heated water stayed at the top. There was very little mixing because of the low flow rate of heated water maintained by the FCV.

- The recovery efficiency of the WHHP-EWH system is a function of the FCV setting. It maintains a constant value for some minimum FCV setting. It decreases rapidly at FCV settings above this minimum.

- Tempering of the hot water at the top of the storage tank by water not as hot occurs during recovery after a heavy draw. This is because supply water entering the bottom of the storage tank after a heavy draw was pumped to the WHHP, heated only to a minimum FCV operating temperature and returned to the top of the $\mathrm{WH}$, causing the temperature at the top of the storage tank to be tempered.

- The daily energy consumption, calculated using the calculation procedure of the current DOE test method, decreases as the ambient temperature increases.

- Allowing the daily energy consumption to vary only within \pm 2 percent of its value at $75^{\circ} \mathrm{F}$ would permit the ambient temperature range to vary no greater than $4.6^{\circ} \mathrm{F}$.

- The calculated daily energy consumption of the system studied agrees well with the measured energy consumption for a 24-hour draw test. 
Table 1. Results of recovery efficiency tests

\begin{tabular}{|c|c|c|c|}
\hline $\mathrm{Ta}\left({ }^{\circ} \mathrm{F}\right)$ & 69 & 75 & 81 \\
\hline$E_{r}$ & 2.19 & 2.34 & 2.43 \\
\hline$P(\mathrm{KW})$ & 1.236 & 1.246 & 1.257 \\
\hline
\end{tabular}

Table 2. Results of standby loss tests (based on $\left.E_{r}=2.40\right)$ *

\begin{tabular}{|c|c|c|c|}
\hline $\mathrm{Ta}\left({ }^{\circ} \mathrm{F}\right)$ & 69 & 75 & 81 \\
\hline $\mathrm{S}(\% / \mathrm{h})$ & 1.31 & 1.23 & 1.14 \\
\hline
\end{tabular}

${ }^{\star} T_{i}=55^{\circ} \mathrm{F}, T_{f}=145^{\circ} \mathrm{F}$, FCV Setting at $115^{\circ} \mathrm{F}$ 
Table 3. Water draw schedule

\begin{tabular}{|c|c|c|}
\hline $\begin{array}{c}\text { Draw } \\
\text { Number }\end{array}$ & Time & $\begin{array}{c}\text { Fractional } \\
\text { Draw } \\
\end{array}$ \\
\hline 1 & $\begin{array}{l}7: 1 \\
7: 1\end{array}$ & .00935 \\
\hline 2 & $\begin{array}{l}7: 5 \\
7: 10\end{array}$ & .234 \\
\hline 3 & $\begin{array}{l}7: 25 \\
7: 25\end{array}$ & .00935 \\
\hline 4 & $\begin{array}{l}8: 0 \\
8: 0\end{array}$ & .00935 \\
\hline 5 & $\begin{array}{l}10: 0 \\
10: 2\end{array}$ & .125 \\
\hline 6 & $\begin{array}{l}10: 22 \\
10: 23\end{array}$ & .0623 \\
\hline 7 & $\begin{array}{l}10: 30 \\
10: 30\end{array}$ & .00935 \\
\hline 8 & $\begin{array}{l}12: 0 \\
12: 0\end{array}$ & .00935 \\
\hline 9 & $\begin{array}{l}12: 45 \\
12: 45\end{array}$ & .00935 \\
\hline 10 & $\begin{array}{l}16: 0 \\
16: 0\end{array}$ & .00935 \\
\hline 11 & $\begin{array}{l}17: 20 \\
17: 20\end{array}$ & .00935 \\
\hline 12 & $\begin{array}{l}18: 0 \\
18: 0\end{array}$ & .00935 \\
\hline 13 & $\begin{array}{l}18: 20 \\
18: 22\end{array}$ & .0467 \\
\hline 14 & $\begin{array}{l}18: 28 \\
18: 30\end{array}$ & .0467 \\
\hline 15 & $\begin{array}{l}18: 36 \\
18: 38\end{array}$ & .0467 \\
\hline 16 & $\begin{array}{l}18: 44 \\
18: 46\end{array}$ & .0467 \\
\hline 17 & $\begin{array}{l}13: 52 \\
18: 54\end{array}$ & .0467 \\
\hline 18 & $\begin{array}{l}22: 0 \\
22: 0\end{array}$ & .00935 \\
\hline 19 & $\begin{array}{l}22: 5 \\
22: 10\end{array}$ & .234 \\
\hline 20 & $\begin{array}{l}22: 25 \\
22: 25\end{array}$ & .00935 \\
\hline 21 & $\begin{array}{l}23: 30 \\
23: 30\end{array}$ & .00935 \\
\hline
\end{tabular}


Table 4. Daily energy consumptions calculated based on measured recovery efficiency and standby loss and assigned temperature rises and water consumption

\begin{tabular}{|c|c|c|c|c|c|c|c|c|c|}
\hline $\begin{array}{c}\mathrm{Ta} \\
\left({ }^{\circ} \mathrm{F}\right)\end{array}$ & $E_{r}$ & $P(K w)$ & $\begin{array}{l}\Delta \mathrm{T}_{5} \\
\left({ }^{\circ} \mathrm{F}\right)\end{array}$ & $\begin{array}{c}U \\
\text { (Gaition) }\end{array}$ & $\begin{array}{c}\mathrm{C}_{\text {wh }} \\
(\mathrm{Btu} / \mathrm{d})\end{array}$ & $\begin{array}{c}\mathrm{S} \\
(\% / \mathrm{hr}\end{array}$ & $\begin{array}{l}\Delta T_{6} \\
\left({ }^{\circ} \mathrm{F}\right)\end{array}$ & $\begin{array}{c}c_{u s} \\
(\mathrm{Btu} / \mathrm{h})\end{array}$ & $\begin{array}{c}\mathrm{Cy} \\
(\mathrm{KWh} / \mathrm{d})\end{array}$ \\
\hline 69 & 2.19 & 1.236 & 90 & 64.3 & 21800 & 1.31 & 90 & 440 & 8.82 \\
\hline 75 & 2.34 & 1.246 & 90 & 64.3 & 20400 & 1.23 & 90 & 413 & 8.30 \\
\hline 81 & 2.43 & 1.257 & 90 & 64.3 & 19650 & 1.14 & 90 & 383 & 7.94 \\
\hline
\end{tabular}

Table 5. Comparison of calculated and measured daily energy consumption

\begin{tabular}{|c|c|c|c|c|c|c|c|c|c|c|c|}
\hline \multicolumn{3}{|c|}{ Recovery } & \multicolumn{3}{|c|}{ Standby } & Calc. & \multicolumn{5}{|c|}{ Draw } \\
\hline$E_{r}$ & $\begin{array}{c}P \\
(K W)\end{array}$ & $\begin{array}{c}\mathrm{Ta} \\
\left({ }^{\circ} \mathrm{F}\right)\end{array}$ & $\stackrel{S}{(\% / h r)}$ & $\begin{array}{c}T w \\
\left({ }^{\circ} \mathrm{F}\right)\end{array}$ & $\begin{array}{c}\mathrm{Ta} \\
\left({ }^{\circ} \mathrm{F}\right)\end{array}$ & $\begin{array}{c}c y \\
(K W h / d)\end{array}$ & $\begin{array}{c}\text { Cyd } \\
\text { (KWh/d) }\end{array}$ & $\begin{array}{c}U \\
\text { (Gallon) }\end{array}$ & $\begin{array}{c}\mathrm{T}_{\text {in }} \\
\left({ }^{\circ} \mathrm{F}\right)\end{array}$ & $\begin{array}{c}T_{0} \\
\left({ }^{\circ} \mathrm{F}\right)\end{array}$ & $\left(\begin{array}{c}\mathrm{Ta} \\
\left({ }^{\circ} \mathrm{F}\right)\end{array}\right.$ \\
\hline 2.34 & 1.246 & 75.4 & 1.23 & 137.8 & 75.9 & 8.30 & 8.15 & 64.3 & 54.0 & 140.0 & 75.6 \\
\hline
\end{tabular}




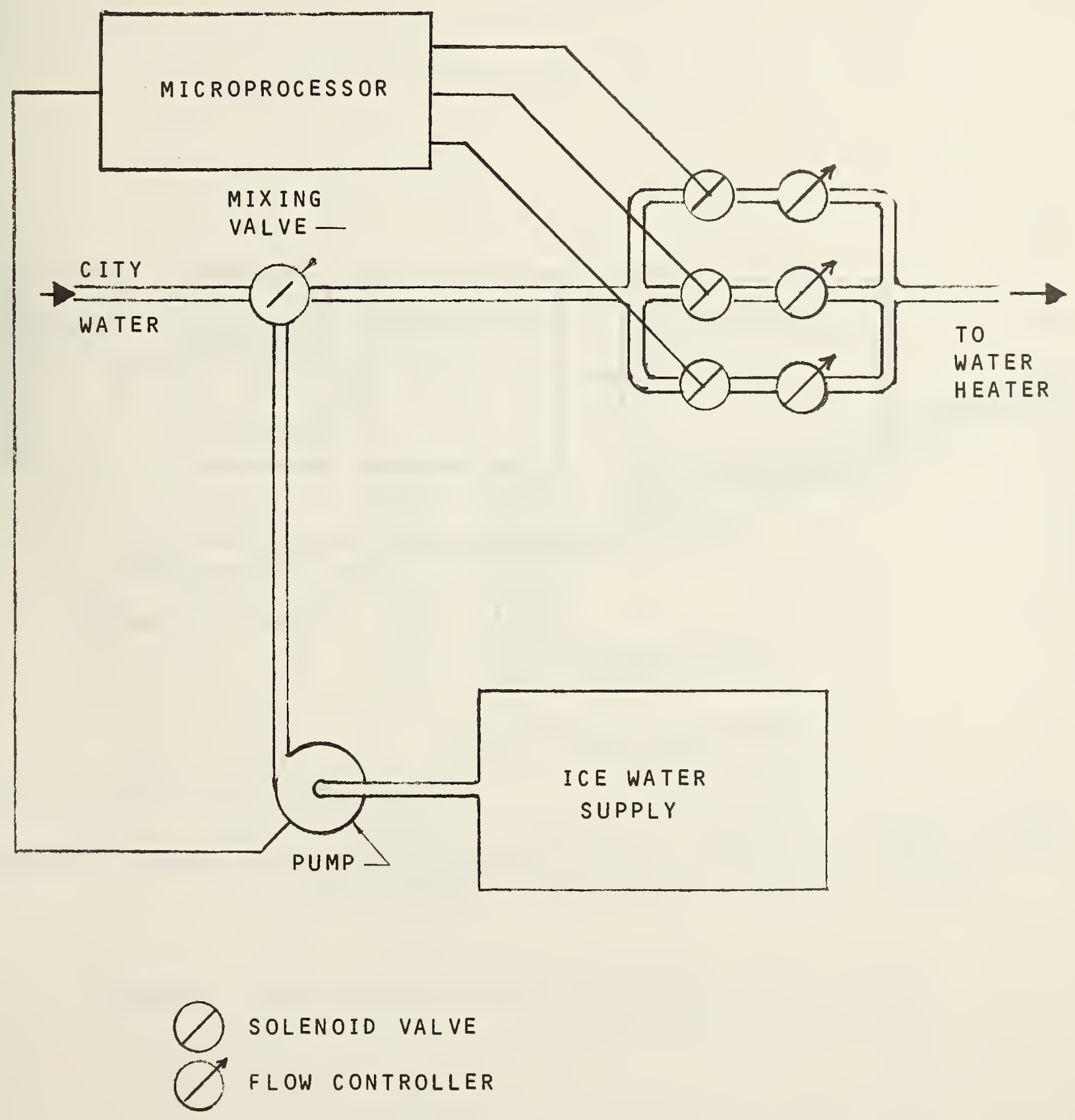

Figure 2. Schematic of water supply system for draw tests 


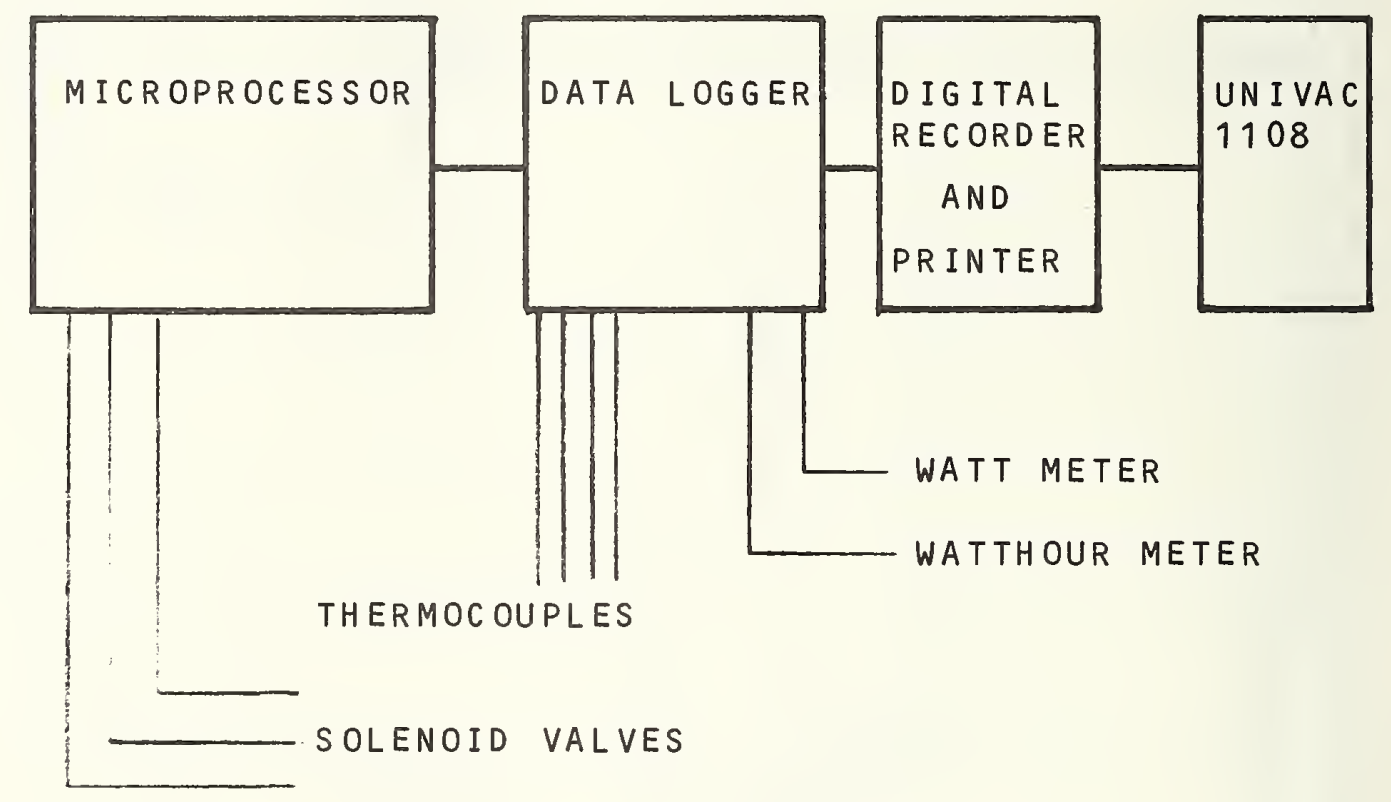

Figure 3. Schematic representation of data acquisition/reduction system 


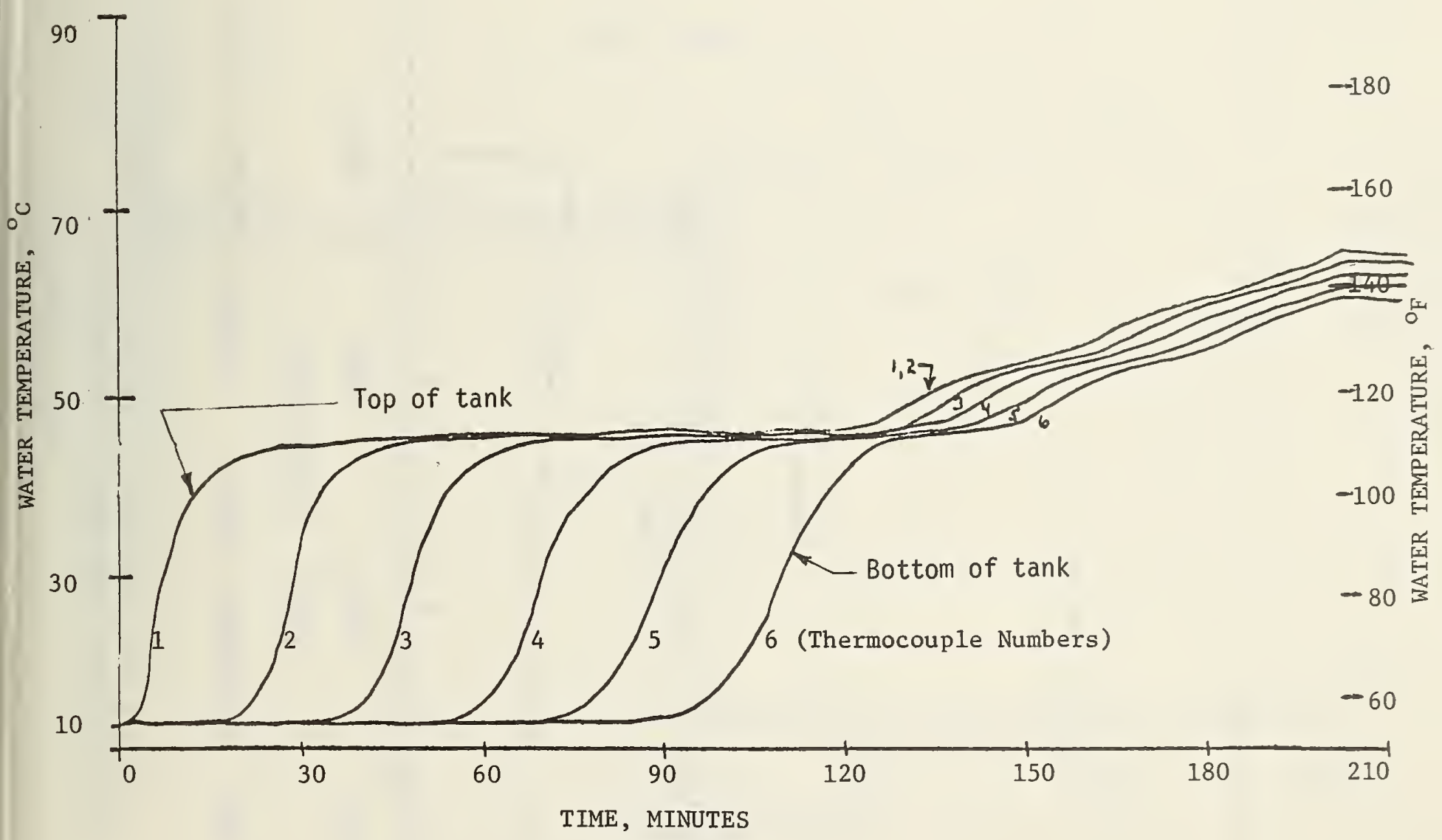

Figure 4. Temperature inside the water storage tank during recovery tests 


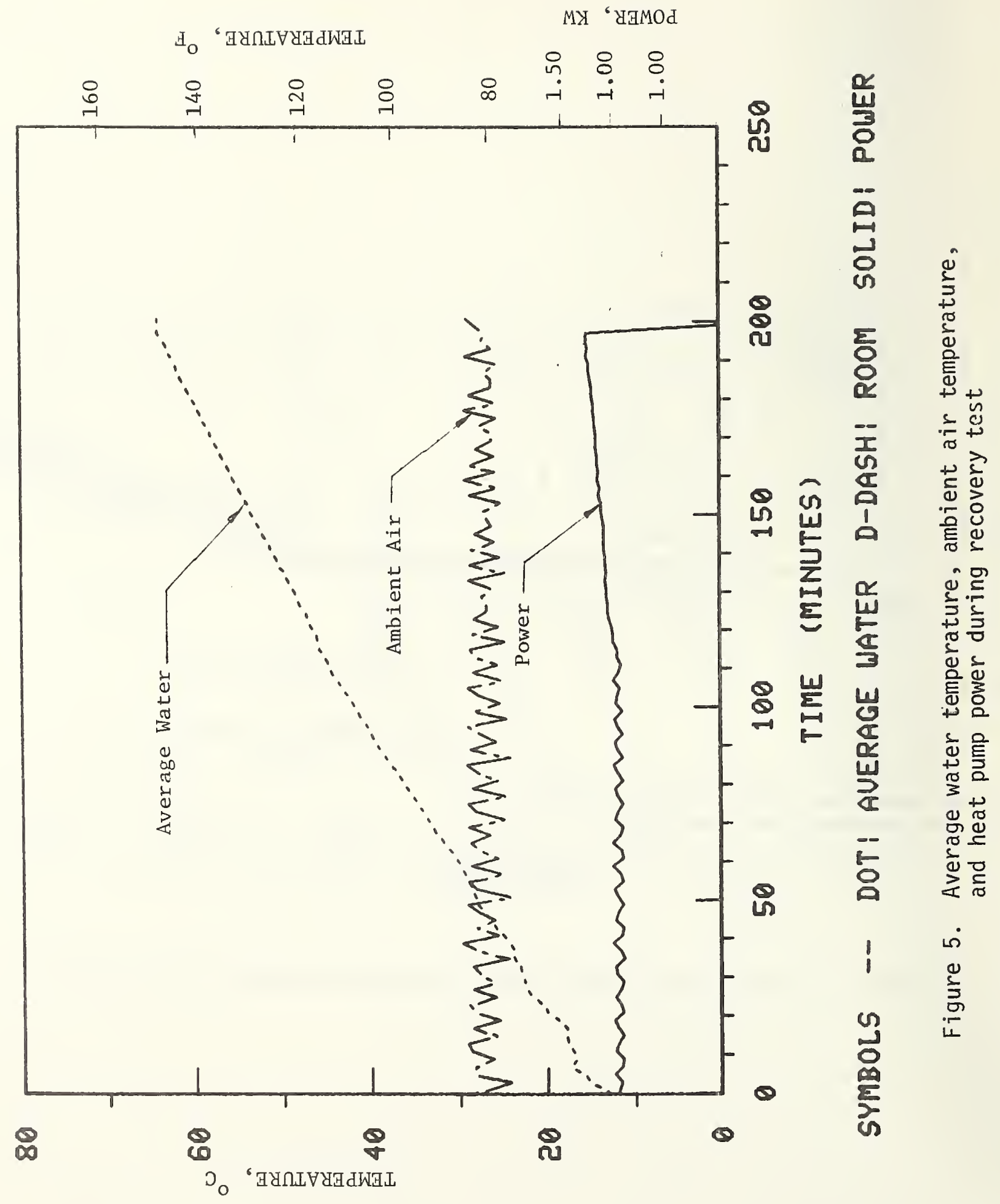




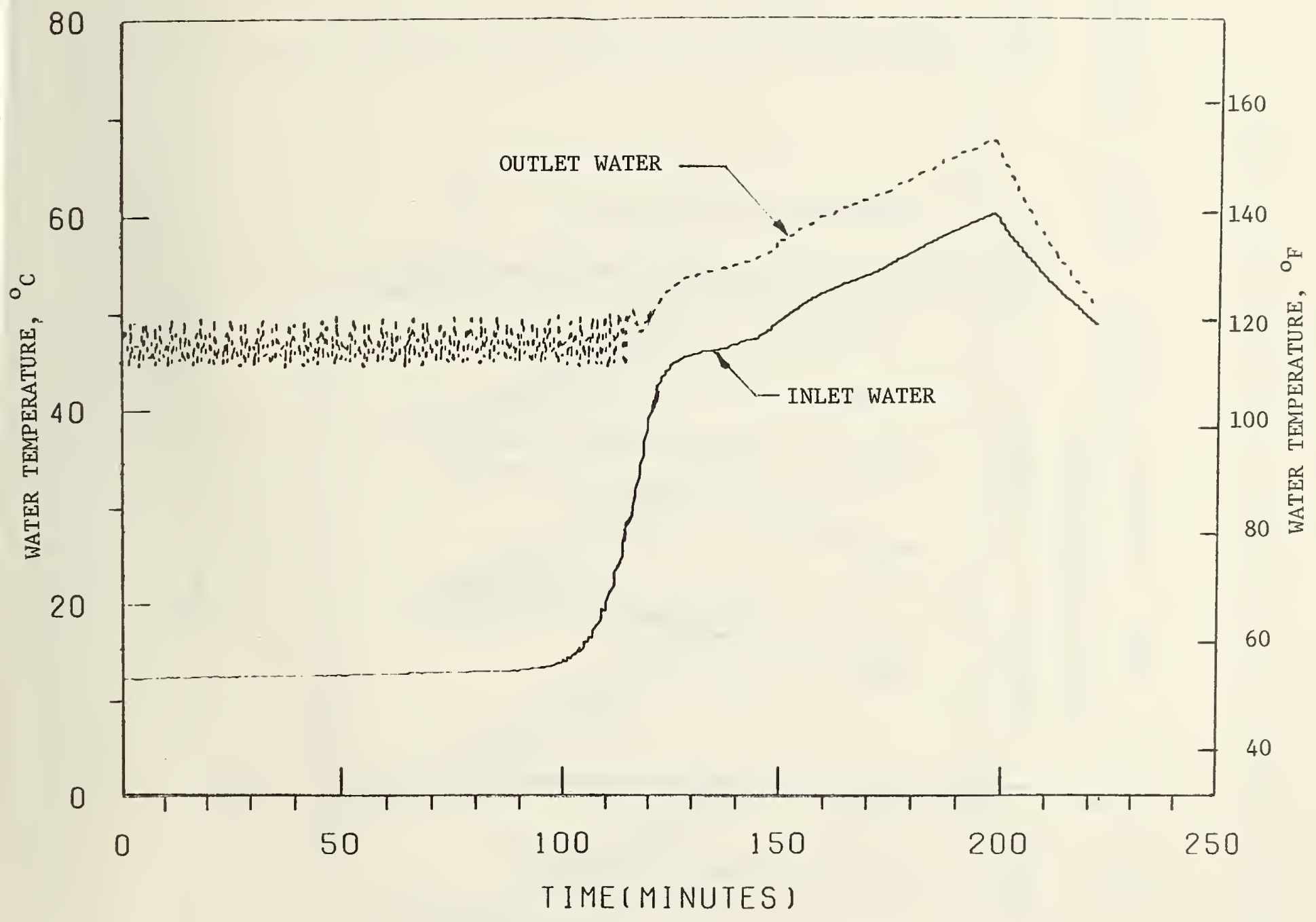

Figure 6. Heat pump inlet and outlet water temperature during recovery test 


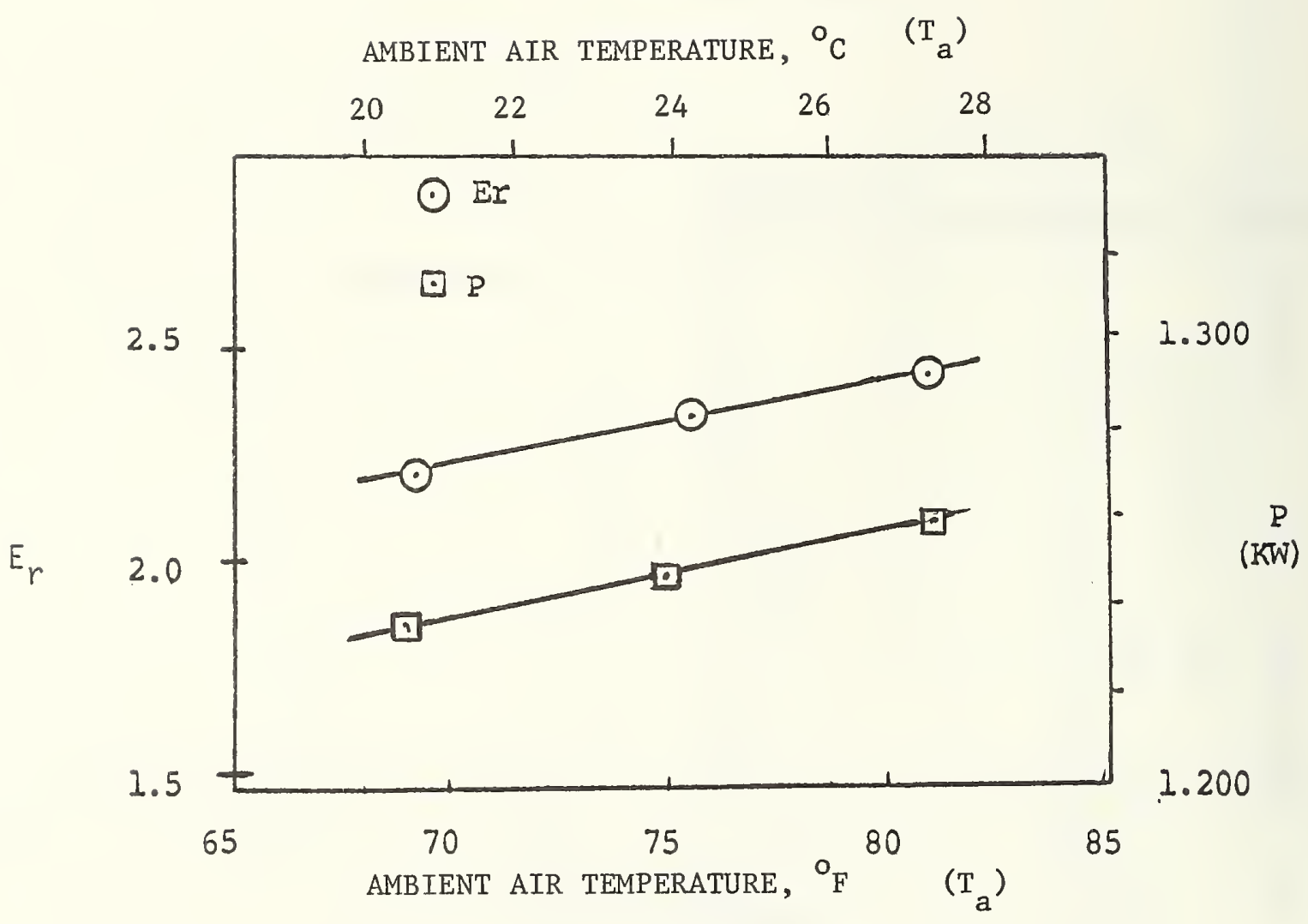

Figure 7. Recovery test efficiency and power input vs. ambient temperature, $T_{i}=12.8^{\circ} \mathrm{C}, T_{f}=62.8^{\circ} \mathrm{C}$. FCV setting $=46.1^{\circ} \mathrm{C}$ 


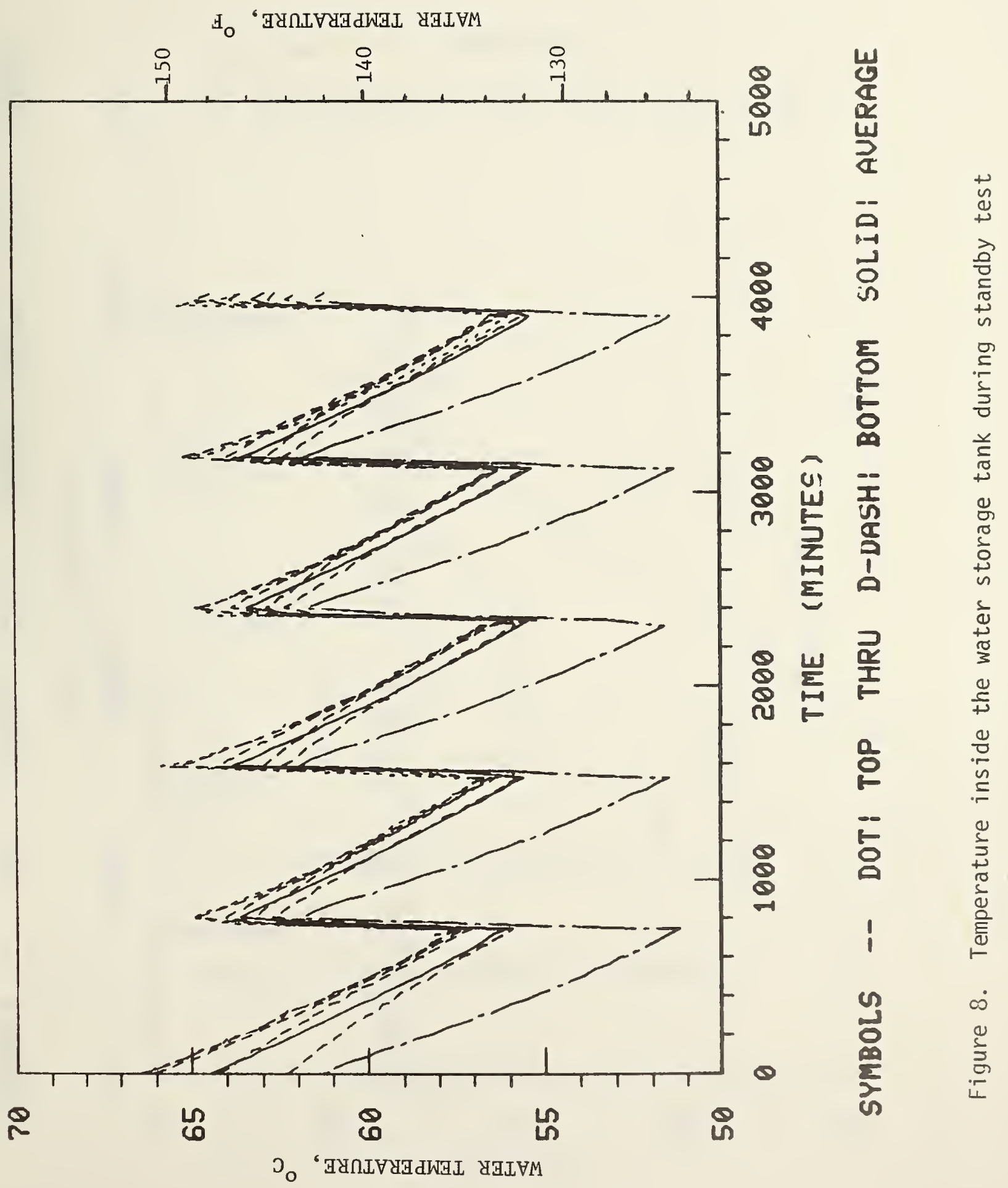




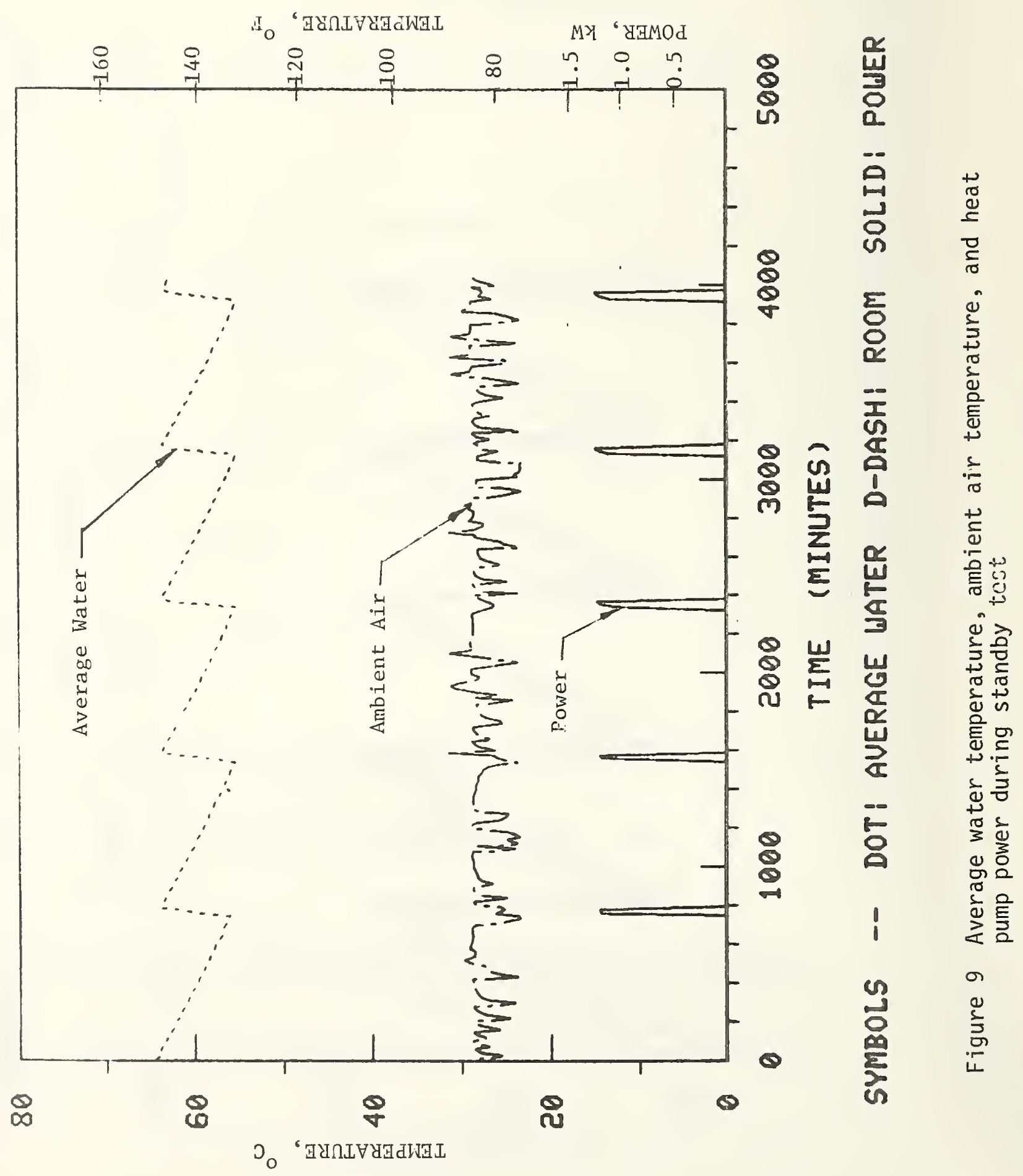




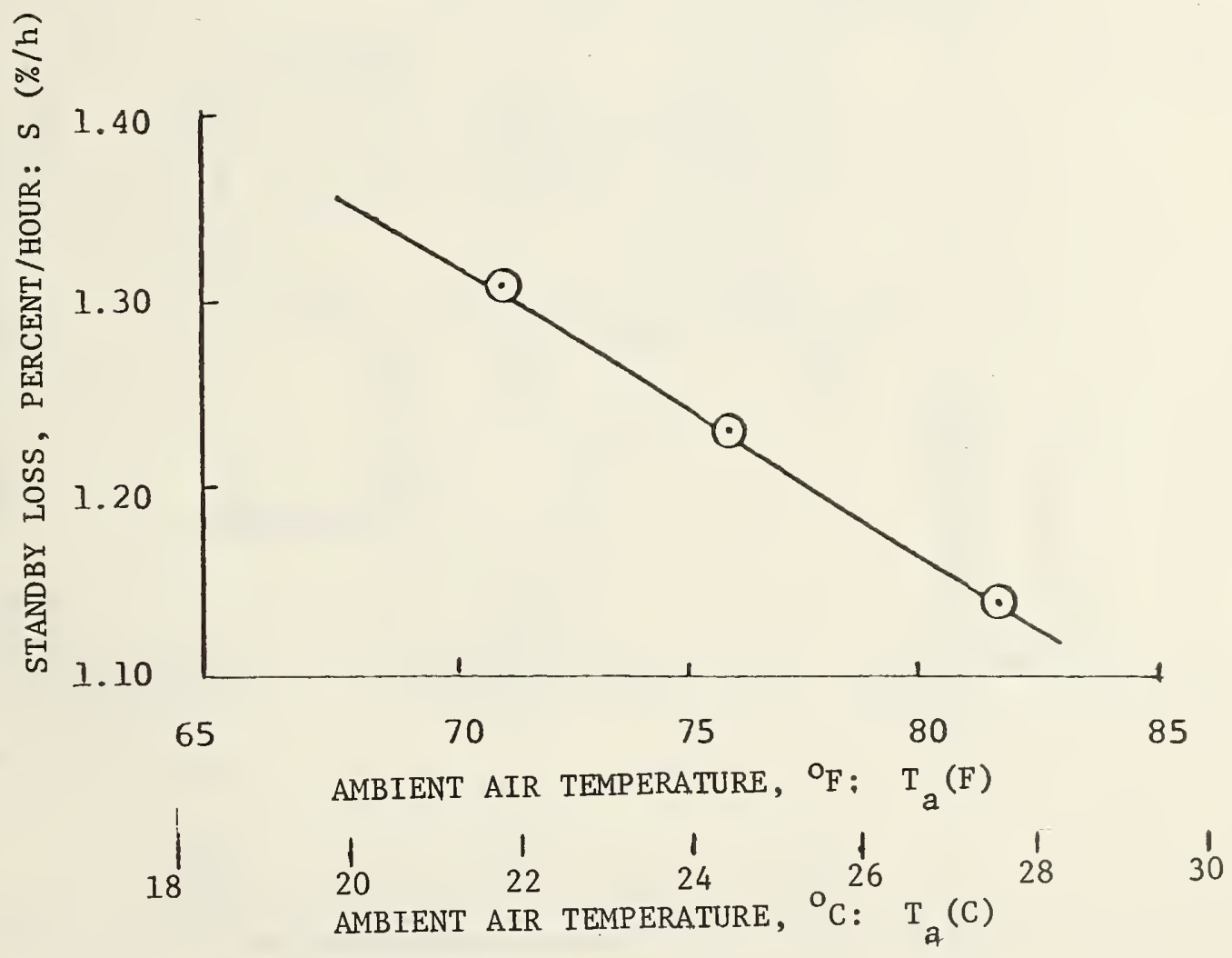

FIGURE 10. STANDBY LOSS VERSUS AMBIENT AIR TEMPERATURE 

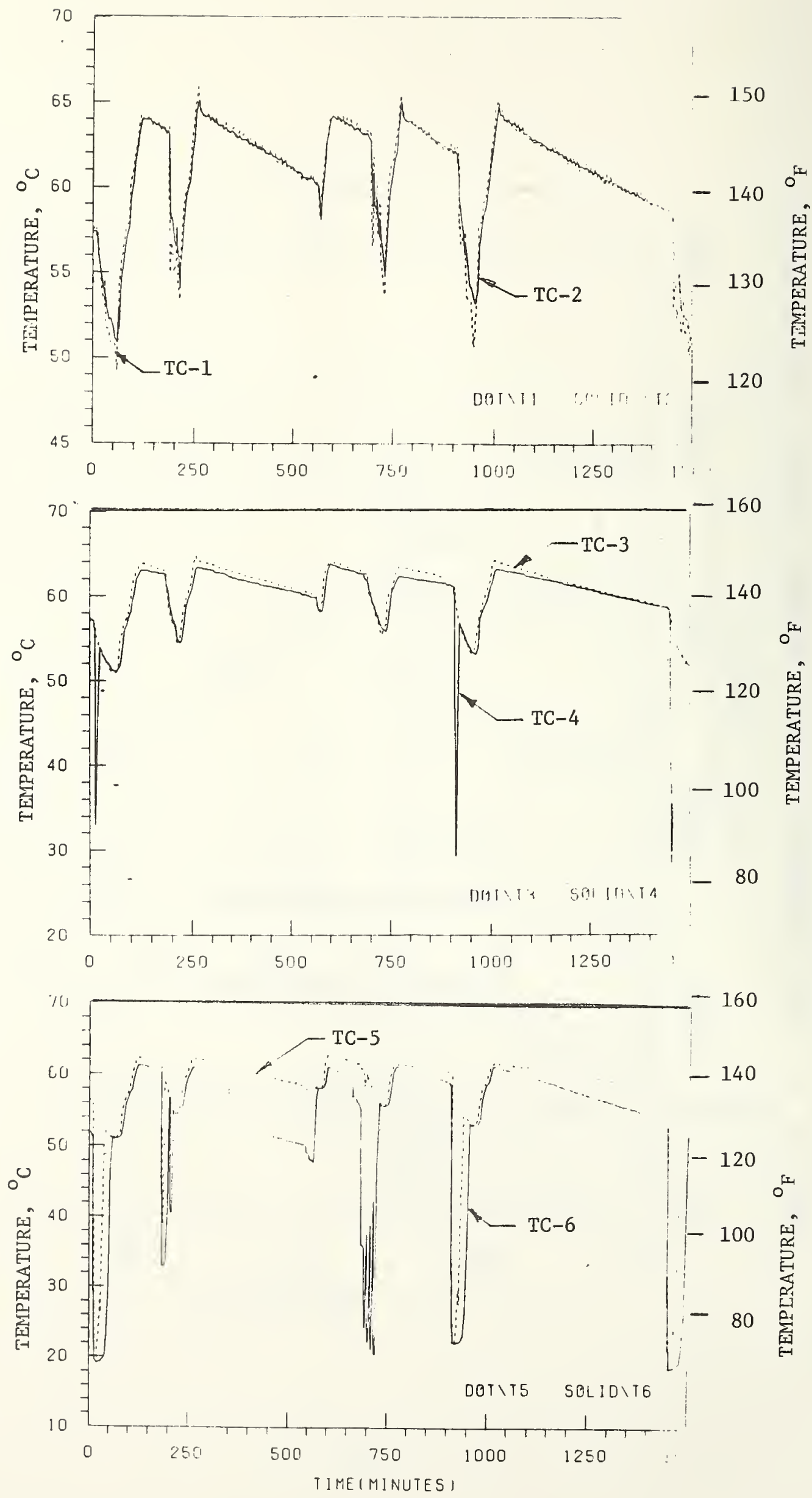

Figure 11. Temperature inside water storage tank during a draw test 


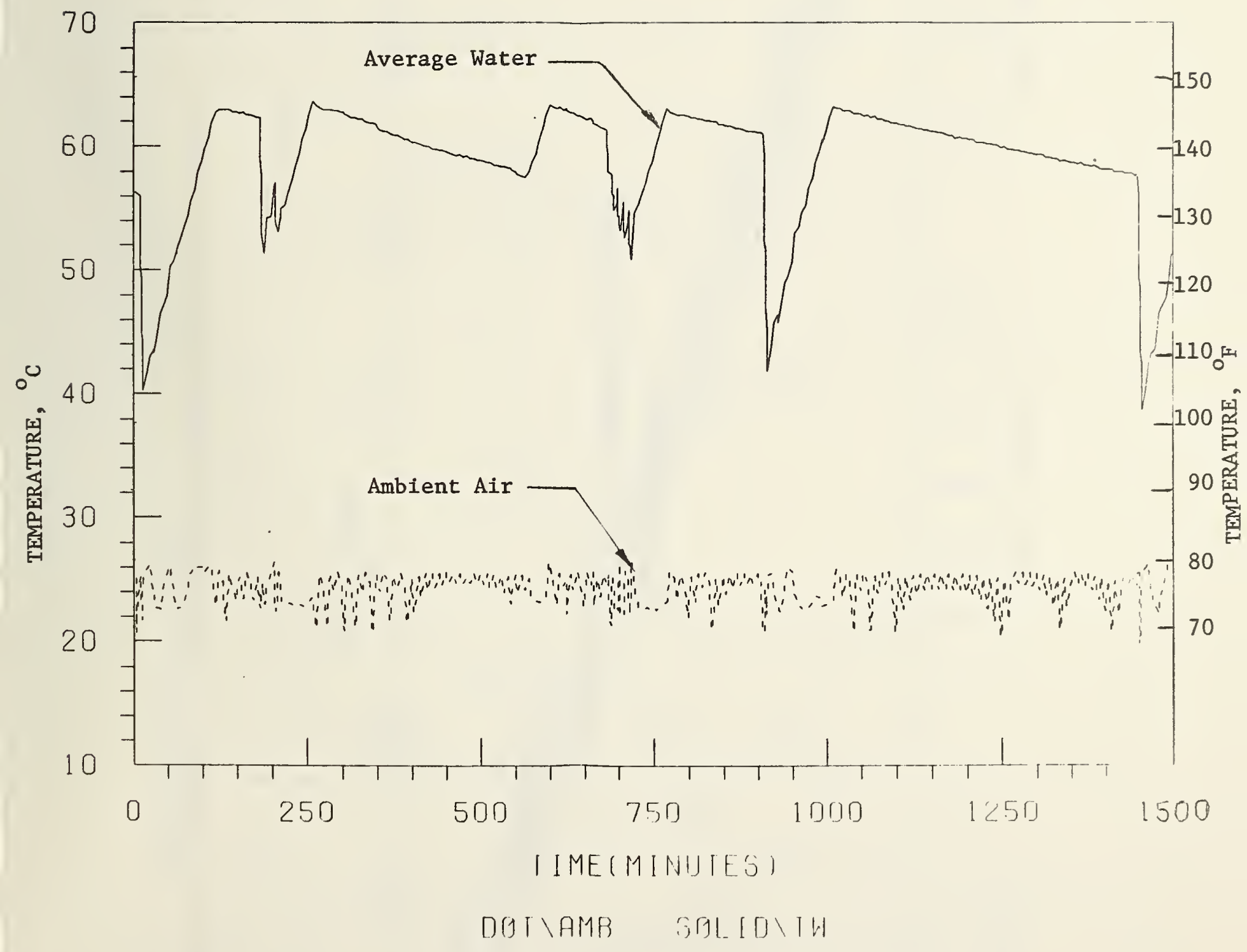

Figure 12. Average water temperature and ambient air temperature during draw test 


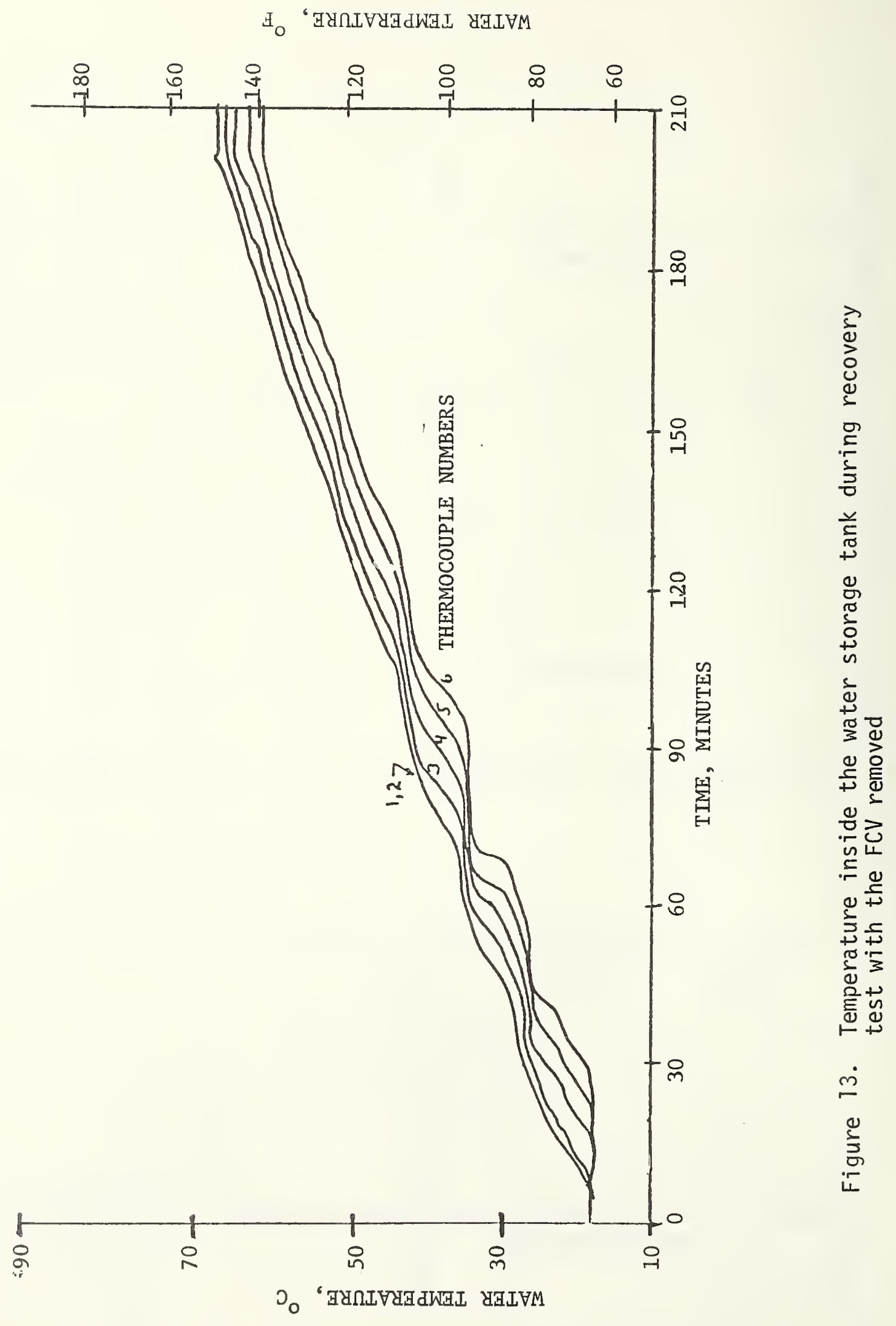



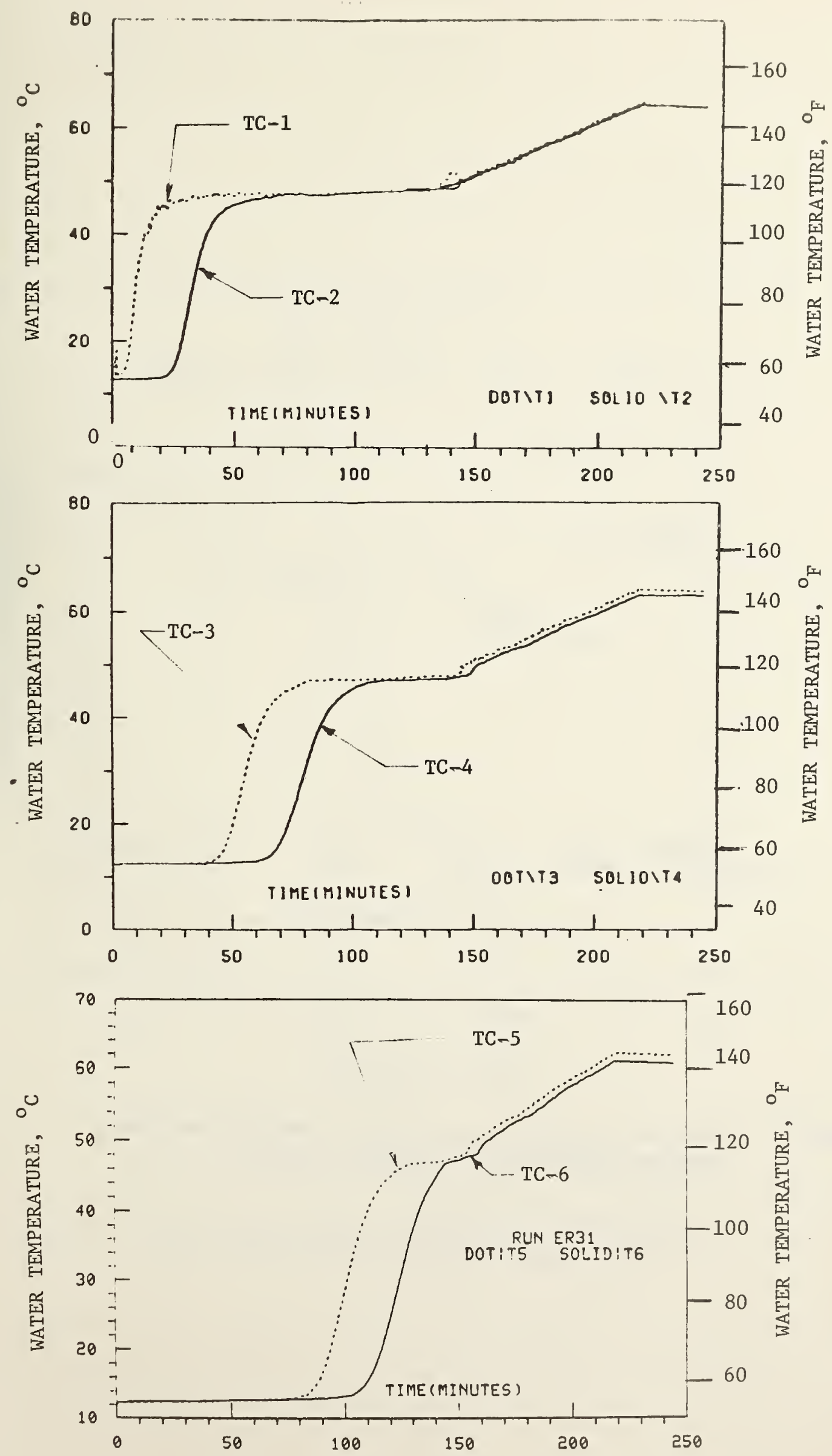

Figure 14. Temperature inside the water storage during recovery test with $\mathrm{FCV}$ setting $=48.3^{\circ} \mathrm{C}$ 


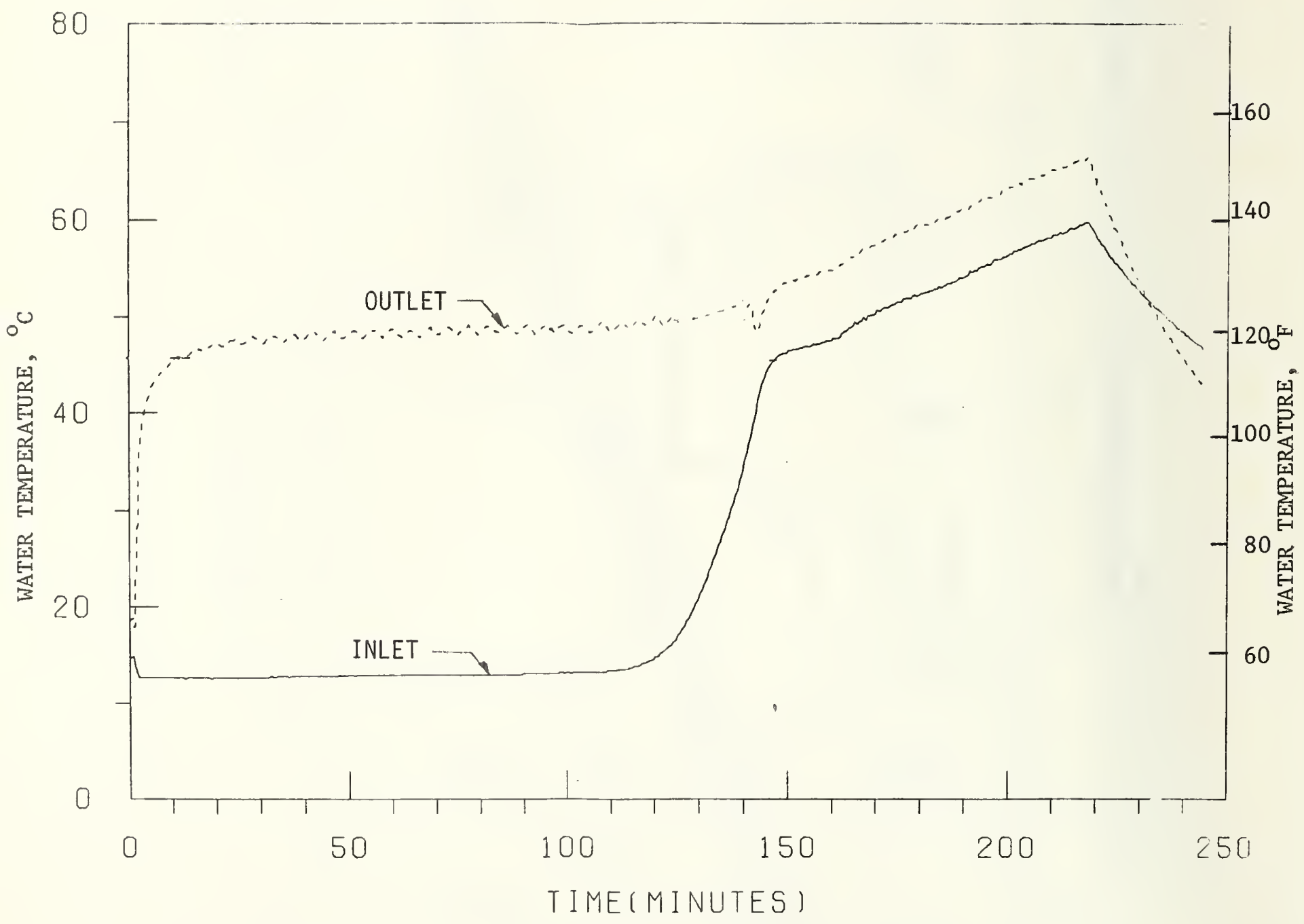

Figure 15. Heat pump inlet and outlet water temperature during recovery test with $\mathrm{FCV}$ setting $=48.3^{\circ} \mathrm{C}$ 


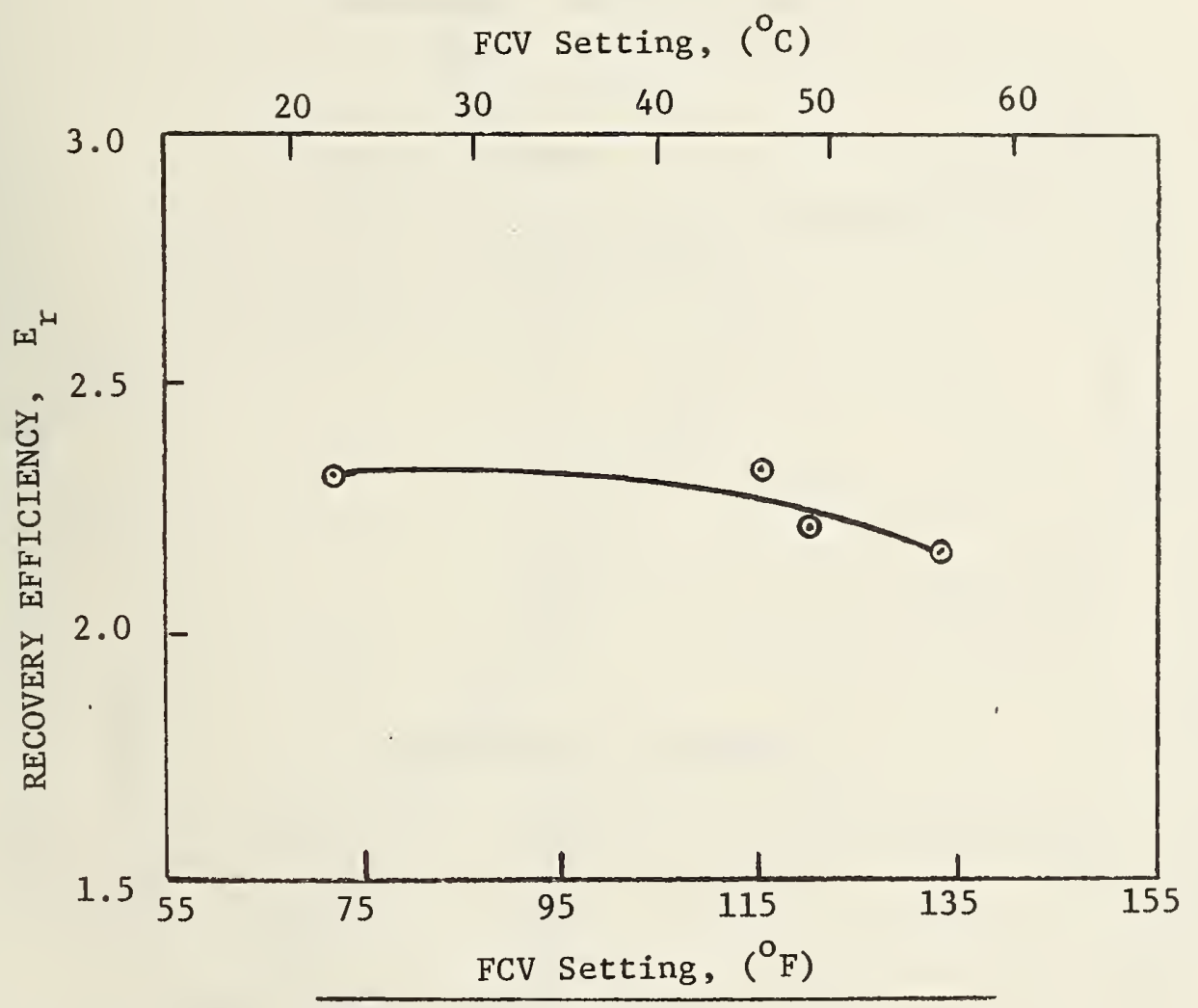

Figure 16. Recovery efficiency at different FCV settings with a $24^{\circ} \mathrm{C}\left(75.2^{\circ} \mathrm{F}\right)$ ambient temperature 


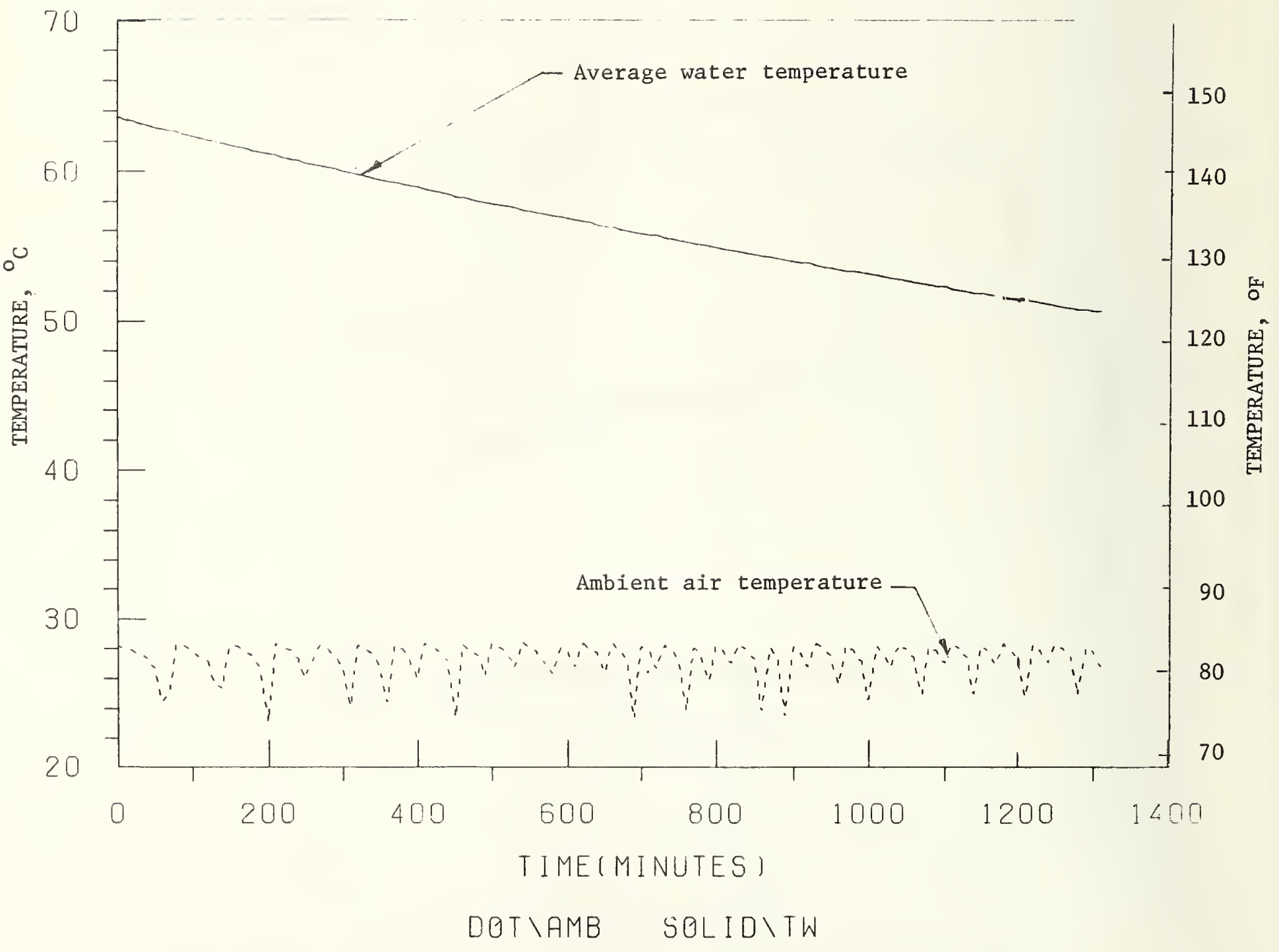

Figure 17. Average water storage tank temperature and ambient temperature during cooldown test 


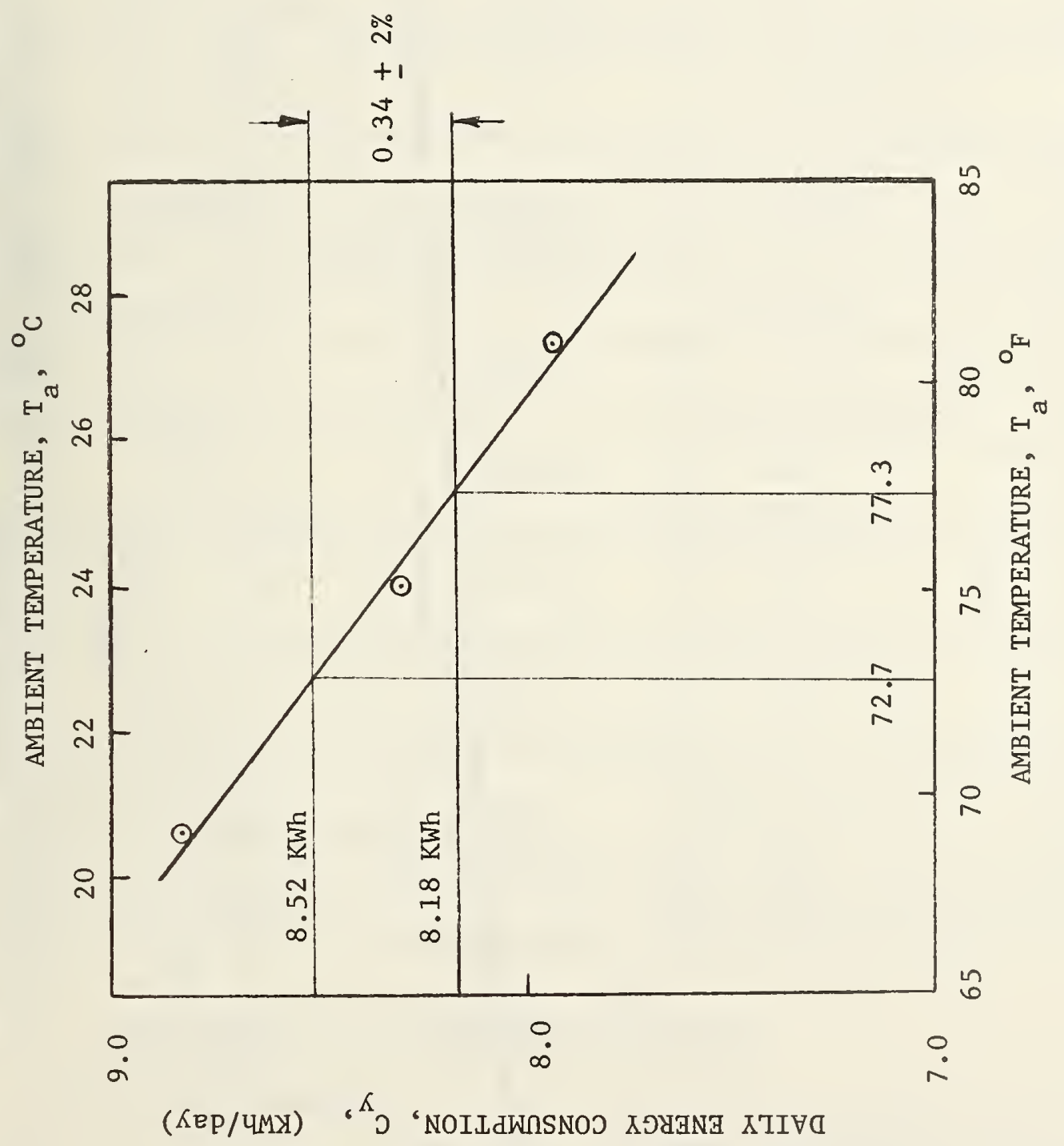

ป 


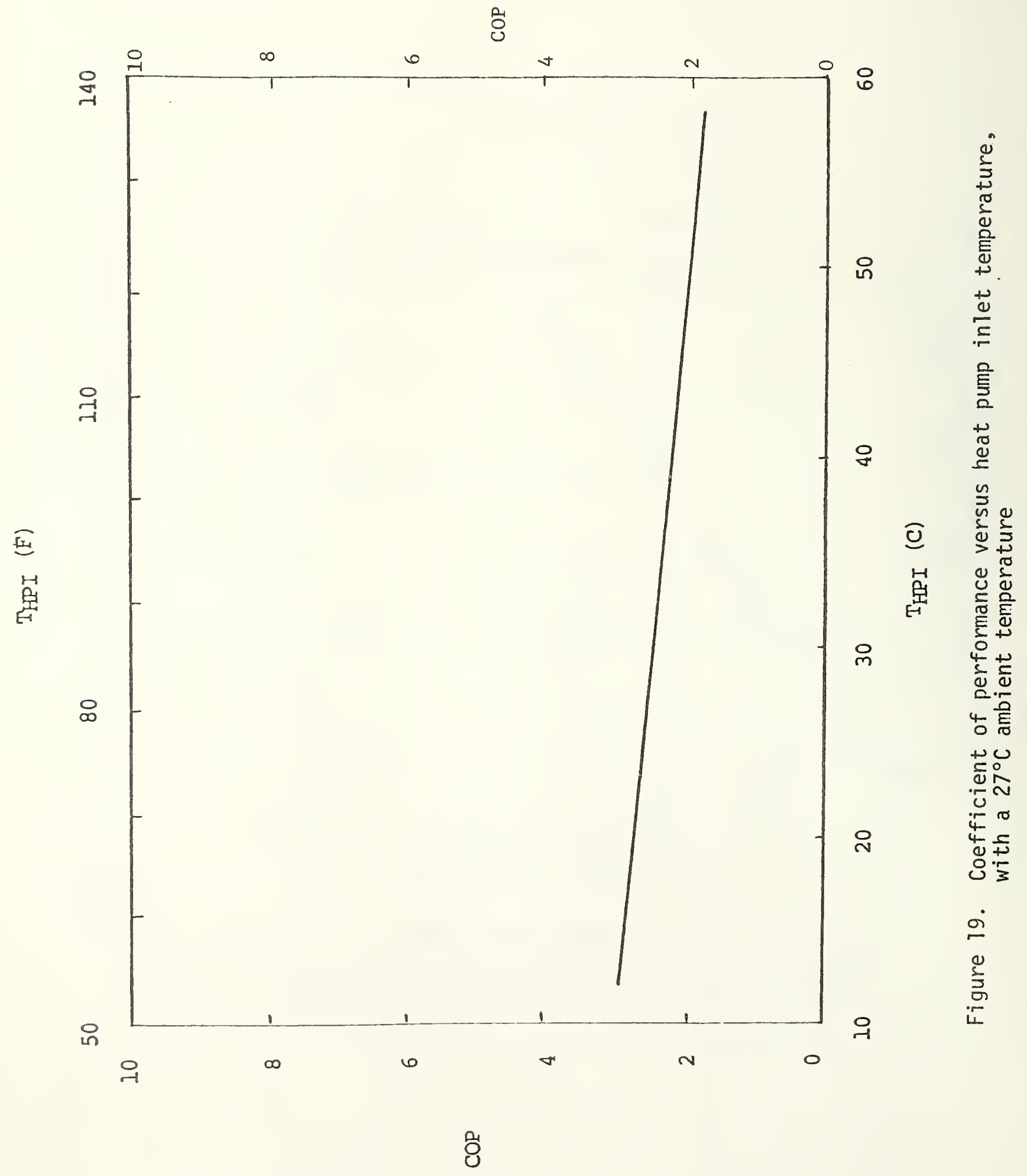


TABLE 6.

UNITS CONVERSION TABLE: SI/INCH-POUND/SI

\begin{tabular}{|c|c|c|}
\hline CONVERT & MULTIPLY BY & TO OBTAIN \\
\hline $\begin{array}{l}\text { gpm } \\
\text { (Gallons/minute) }\end{array}$ & 0.06309 & $\begin{array}{l}\mathrm{L} / \mathrm{s} \\
\text { (Liters/second) }\end{array}$ \\
\hline $\begin{array}{c}\mathrm{L} / \mathrm{s} \\
\text { (Liters/second) }\end{array}$ & 15.85 & (Gallons/minute) \\
\hline $\begin{array}{c}\mathrm{g} \\
\text { (Gallons) }\end{array}$ & 3.785 & $\begin{array}{c}\mathrm{L} \\
\text { (Liters) }\end{array}$ \\
\hline $\begin{array}{c}\mathrm{L} \\
\text { (Liters) }\end{array}$ & 0.2642 & $\cdot \stackrel{g}{g}$ \\
\hline $\begin{array}{c}\text { in } \\
\text { (Inches) }\end{array}$ & 2.54 & $\begin{array}{c}\mathrm{cm} \\
\text { (Centimeters) }\end{array}$ \\
\hline $\begin{array}{c}\mathrm{cm} \\
\text { (Centimeters) } \\
\end{array}$ & 0.3937 & $\begin{array}{c}\text { in } \\
\text { (Inches) }\end{array}$ \\
\hline $\begin{array}{c}\mathrm{ft} \\
(\mathrm{Feet})\end{array}$ & 0.3048 & $\begin{array}{c}\mathrm{m} \\
\text { (Meters) }\end{array}$ \\
\hline $\begin{array}{c}\mathrm{m} \\
\text { (Meters) }\end{array}$ & 3.281 & $\begin{array}{c}f t \\
(f \text { eet })\end{array}$ \\
\hline $\begin{array}{l}\text { BTU } \\
\text { British Thermal Units) }\end{array}$ & 1.055 & $\begin{array}{l}\text { kJ } \\
\text { (kilojoules) }\end{array}$ \\
\hline $\begin{array}{c}\mathrm{kJ} \\
\text { (kilojoules) }\end{array}$ & 0.9479 & $\begin{array}{l}\text { BTU } \\
\text { (British Thermal Units) }\end{array}$ \\
\hline
\end{tabular}

TEMPERATURE (T), CONVERSION EQUATIONS:

FOR TEMPERATURE USE:

$$
\begin{array}{ll}
{ }^{\circ} \mathrm{F} \text { to }{ }^{\mathrm{O}} \mathrm{C}: & {\left[(\mathrm{T}){ }^{\mathrm{O}} \mathrm{F}-32{ }^{\circ} \mathrm{F}\right](5 / 9)=(\mathrm{T}){ }^{\circ} \mathrm{C}} \\
{ }^{\circ} \mathrm{C} \text { to }{ }^{\circ} \mathrm{F} & {\left[(\mathrm{T}){ }^{\circ} \mathrm{C}\right](9 / 5)+32^{\circ} \mathrm{F}=(\mathrm{T}){ }^{\mathrm{O}} \mathrm{F}}
\end{array}
$$

FOR TEMPERATURE DIFFERENTIALS OR TOLERANCES USE:

$$
\begin{array}{ll}
{ }^{\circ} \mathrm{F} \text { to }{ }^{\circ} \mathrm{C}: & (\mathrm{T})^{\mathrm{O}} \mathrm{F}(5 / 9)=(\mathrm{T})^{\circ} \mathrm{C} \\
{ }^{\mathrm{O}} \mathrm{C} \text { to }{ }^{\mathrm{O}} \mathrm{F} & (\mathrm{T})^{\circ} \mathrm{C}(9 / 5)=(\mathrm{T})^{\circ} \mathrm{F}
\end{array}
$$




\section{REFERENCES}

[1] Wan, C.A., "Energy Test Method Development for Electric Heat Pump Water Heaters," NBSIR 79-1951, Center for Consumer Product Technology, National Bureau of Standards, Washington, D.C., January 1980

[2] Appendix E - Uniform Test Method for Measuring the Energy Consumption of Water Heaters - The Code of Federal Regulations. Title 10, Chapter II, Part 430, Subpart B, published in Federal Register, Vol. 42, No. 192, Tuesday, October 4, 1977, p. 54117-54119.

[3] Wan, C.A., "Computer Simulation of Water Heater Standby Loss, Heat Transfer in Energy Conservation," Goldstein, R.J., et a1, editors, 1977 WAM, ASME.

[4] Sushinsky, G.F., and Kweller, E.R., "Proposed Amendments to Test Procedures for Water Heaters to Include Heat Pump Water Heaters," Letter Report prepared for Department of Energy, April 1981. 
NBS-114A (REV. 2-8C)

U.S. DEPT. OF COMM

BIBLIOGRAPHIC DATA

SHEET (See instructions)

1. PUBLICATION OR

REPORT NO.

NBSIR $81-2372$

January 1982

4. TITLE AND SUBTITLE

Development of Energy Test Methods for a Dedicated Water Heating Heat Pump:

5. $A U T H O R(S)$

C. Andrew Wan, Robert L. Palla, Jr., James E. Harris

6. PERFORMING ORGANIZATION (If joint or other than NBS, see instructions)

NATIONAL BUREAU OF STANDARDS

DEPARTMENT OF COMMERCE

WASHINGTON, D.C. 20234

7. Contract/Grant No.

8. Type of Report \& Period Covered

9. SPONSORING ORGANIZATION NAME AND COMPLETE ADDRESS (Street, City. Stote. ZIP)

United States Department of Energy

and

Oak Ridge National Laboratory

Oak Ridge, Tennessee

10. SUPPLEMENTARY NOTES

[D Document describes a computer program; SF-185, FIPS Software Summary, is attached.

11. ABSTRACT (A 200-word or less factual summary of most significant information. If document includes a significant bibliography or literature survey. mention it here)

Modifications of the DOE test procedure for water heaters "Uniform Test Method for Measuring the Energy Consumption of Water Heaters" were made to include a dedicated water heating heat pump, system equipped with a 50 gallon electric water heater tank. Also presented are laboratory tests and results which provided the basis for the test methods used. Tests included determination of recovery efficiency, standby loss, and water heater jacket loss -- a 11 under static or no-draw conditions -- and a dynamic test in which water is withdrawn according to a "typical-use" schedule. Energy requirements predicted by the proposed (static) procedure were in good agreement with measured energy consumption for the dynamic test in limited testing.

12. KEY WORDS (Six to twelve entries; alphabetical order: capitalize only proper names; and separate key words by semicolons) energy conservation; energy consumption; flow control valve; heat pump; stratification; test method; water heater

13. AVAILABILITY

X Unlimited

For Official Distribution. Do Not Release to NTIS

Order From Superintendent of Documents, U.S. Government Printing Office, Washington, D.C. 20402.

X] Order From National Technical Information Service (NTIS), Springfield, VA. 22161
14. NO. OF

PRINTED PAGES

52

15. Price 


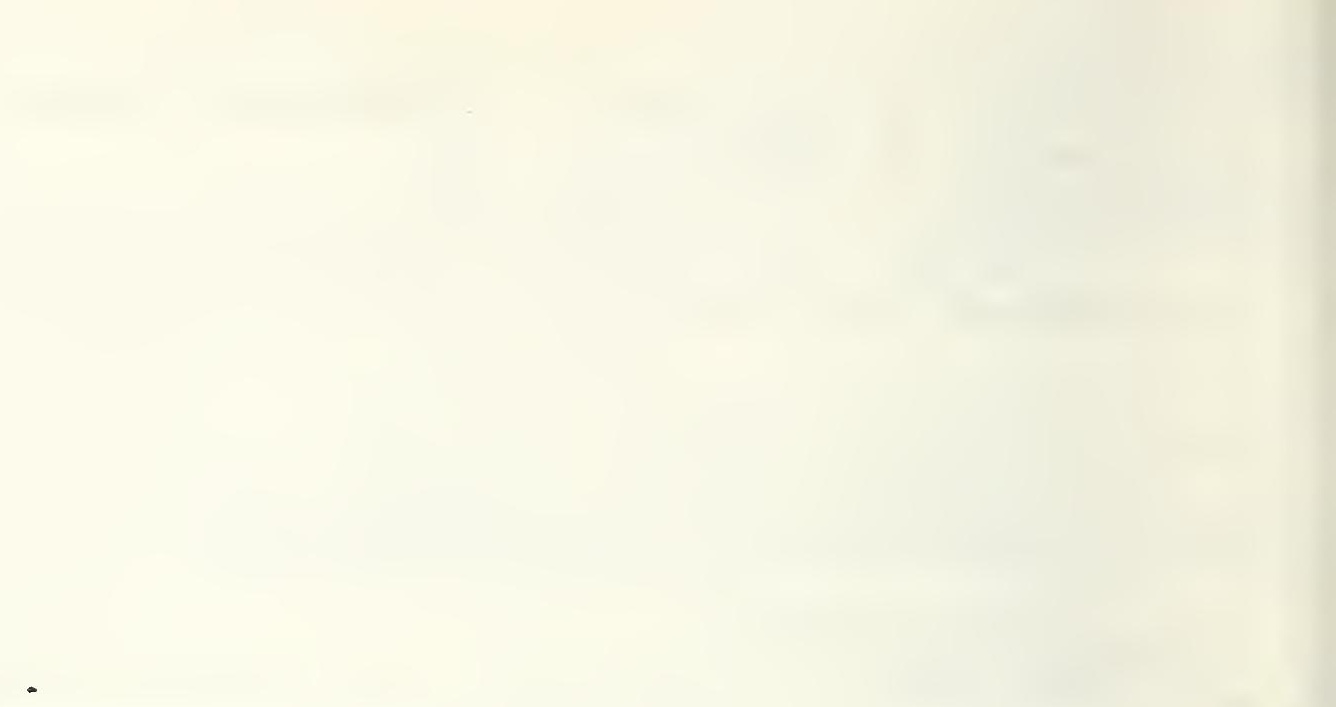





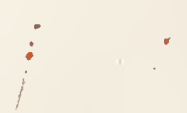

